\title{
The Long-Term Significance of Printed Ephemera
}

SinCE IT IS UNLIKELY THAT EVERY RBM reader is a committed ephemerist, I shall begin with a few generalities that, I daresay, will be all too familiar to many. The word "ephemera" is Greek in derivation and stems from the words EPI = through and HEMERA = the day, which is why those with a more thorough classical education than I have had pronounce the word ephemera with a long middle "e." On this particular matter I am firmly with most Americans in saying ephemera (with a short "e"). The word is by no means new, and has long been used by zoologists to describe the mayfly and other insects that live for one day only, and a century or so ago was applied to fevers that lasted for a similar period of time. By extension, it is now applied by people like us to describe documents that have relevance only for a short time, normally the day or days of the event or situation they relate to.

The working definition for ephemera used by the Ephemera Society in Britain for some thirty years is "the minor transient documents of everyday life," and the term is applied equally to manuscript and printed items. ${ }^{1}$ While not a perfect definition by any means (many people, particularly those on this side of the Atlantic, find it rather pompous, and it has decidedly fuzzy edges that would not be fruitful for me to explore here), it is probably the best we have and provides us with a good starting point. Well over a century ago, however, the printing trade adopted the terms "jobbing work" or "jobbing printing" to describe printed documents of this kind. ${ }^{2}$

1. See M. Rickards, Collecting Printed Ephemera (Oxford: Phaidon/Christie's, 1988), 13, though in this instance the words "minor" and "transient" are transposed. The definition appeared first in literature of the Ephemera Society, which was founded by Rickards and others in 1975.

2. J.C. Jacobi, The Printers' Vocabulary... Mostly Relating to Letterpress Printing (London: Chiswick Press, 1888), defines "Job" as "Any work which makes less than a sheet," and "Job house" as "A term applied to printing offices distinct from book or newspaper offices." "Jobbing," in the more general sense of doing odd jobs, dates from the eighteenth century (OED). Jobbing, as applied to printing, is defined by the Shorter Oxford English Dictionary (5th ed., 2002) as "the printing of small miscellaneous items." The French term for "jobbing printing" was "ouvrages de ville," later "travaux de ville." The Dictionnaire de l'Académie française, 6th ed. (Paris, 1835) defines "Ouvrages de ville" under, and in contrast to, "Labeur": "Labeur, en termes d'Imprimerie, se dit Des ouvrages considérables et tirés à grand nombre, par opposition Aux ouvrages de peu d'étendue, qui se tirent ordinairement à petit nombre, et qu'on nomme Ouvrages de ville." [Labeur, as a printing term, in contrast to small-scale works normally printed in short runs, which are called ouvrages de ville.] 
"Ephemera” and "jobbing printing" are not precisely synonymous—strictly speaking, jobbing printing relates to work other than book, periodical, or newspaper printing - but it will be appreciated that much printing of this kind has only a very brief shelf life and can therefore be classed as ephemera.

My main aim in this paper, as my title suggests, is to point to the long-term significance of these short-term items. But I have a secondary, more controversial aim: to challenge the position - which I believe to be widely held - that print culture and book culture amount to much the same thing. Not many scholars would admit publicly to holding such a view, but in practice the very real distinction between the two has become blurred by default. Clearly, one of the reasons for this has to do with the availability of material for study: whereas books have been preserved in libraries from ancient times, and in more recent centuries have been joined there by newspapers and periodicals, most printed ephemera have survived only by chance. Some libraries accept them, others do not; most regard them as of only marginal concern, and they are not normally included in arrangements for legal deposit. ${ }^{3}$ It is hardly surprising, therefore, that printing historians have focused on the book, whether this is explicitly stated in the titles of their publications or not. ${ }^{4}$

But things are changing, and one of the turning points in institutions came with a decision made by the Bodleian Library in Oxford in the 1960s. In the interwar years it was not uncommon for the library to dispose of items of printed ephemera, some of them centuries old, to what was then called the "Constance Meade Collection of Oxford University Press." These items had been officially and somewhat imperiously designated by senior curators at the time as "material of no literary or artistic value ... which it is not in the interests of the Library to include in the general catalogue or to preserve on its shelves." University Press, they were lovingly cared for by the printer to the University, John

3. This was so in France in the late nineteenth century. A law on the liberty of the press of 29 July 1881 (art. 3) specifically exempted from legal deposit "les bulletins de vote, les circulaires commerciales ou industrielles et les ouvrages dits de ville ou bilboquets" (ballot papers, trade or industrial circulars, and jobbing printing or ephemera). Cited in A. Valette, Manuel pratique du lithographe, 3rd ed. (Paris, 1903), 347. In recent years, legislation in France concerning deposit has been revised to give greater coverage; see, for example, Bibliothèque municipale (Lyon), Le dépôt legal [Livre] realisé par la Bibliothèque municipale de Lyon (Lyon: Bibliothèque municipale, 1999). At the other extreme, Sweden requires all printed matter to be deposited in two locations (and several other institutions on demand).

4. A few well-known general works illustrate the point: W. Chappell, A Short History of the Printed Word (New York: Dorset Press, 1989), E.L. Eisenstein, The Printing Press as an Agent of Change, 2 vols. (Cambridge, 1979), L. Febvre and H-J. Martin, L'Apparition du livre (Paris: Editions Albin Michel, 1958; translated as The Coming of the Book, London, 1976, and later editions), S. Morison, Four Centuries of Fine Printing (London: Ernest Benn, 1924; 2nd rev. ed., 1949), S.H. Steinberg, Five Hundred Years of Printing (Harmondsworth: Penguin books, 1955, and later editions; new ed. rev. by John Trevitt, The British Library and Oak Knoll Press, 1996).

5. Cited by J.A. Lambert from the Bodleian Library Record, October 1938, in her text to a Bodleian Library exhibition catalogue, A Nation of Shopkeepers: Trade Ephemera from 1654 to the 1860 s in the John Johnson Collection (Oxford: Bodleian Library, 2001), iv. 
Johnson, and his helpers and, later, by his successors, along with large quantities of ephemera that had been acquired from other sources.

That was the position until 1968. In that year the Bodleian Library had a change of heart and eagerly acquired the entire collection of ephemera at the Press-thereafter referred to as the "John Johnson Collection"-including those items that it had once disposed of as "not in the interests of the library to keep." "This change of position by a world-famous library reflected a growing interest in the serious study of ephemera elsewhere and helped to change attitudes toward ephemera in the curatorial world. And in recent years the relative ease of digitizing such material, coupled with the usefulness of doing so, has quickened the pace of this shift.

Today, collections of ephemera that were acquired or built up decades or even centuries ago are being taken seriously by libraries, museums, and archives throughout the world. It is perhaps invidious to point to examples, but I shall refer to a few significant exhibitions in recent years: "Ephemera: les imprimés de nos jours" at the Musée de l'imprimerie de Lyon in 2001; "Questions d'étiquettes," a wide-ranging exhibition of labels held at the Bibliothèque Forney, Paris, in 2002; and an exhibition focusing on trade cards, "A Nation of Shopkeepers," organized at the Bodleian Library in 2001 by Julie Anne Lambert (whose article also appears in this issue of $R B M)$.

Changing attitudes to ephemera-illustrated most spectacularly in the United States by the "American Memory" project of the Library of Congress-are bound to have a bearing on future research and scholarship in what is increasingly being called "print culture," though, sadly, it is now too late to form representative collections of many categories of ephemera. The damage caused by earlier attitudes to such documents has already been done. Those who work regularly with ephemera know that, in many respects, they experience only the tip of a vast iceberg of material that must once have existed, and this is particularly so when it comes to ephemera produced before the industrial age. Although some early material does exist in public collections, it tends to fall into certain well-defined categories, such as proclamations; ballads and theater bills; bills of mortality (figure 1) and trade cards.

The comparative neglect of ephemera by historians of printing and print culture is therefore understandable. But one of its consequences has been a narrow focus on the book and, therefore, I believe, a misrepresentation of these broader fields of study. So much has been lost of printed ephemera from the past, at least when

6. The transfer is referred to in the foreword by Bodley's Librarian to The John Johnson Collection: Catalogue of an Exhibition (Oxford: Bodleian Library, 1971), 3. 


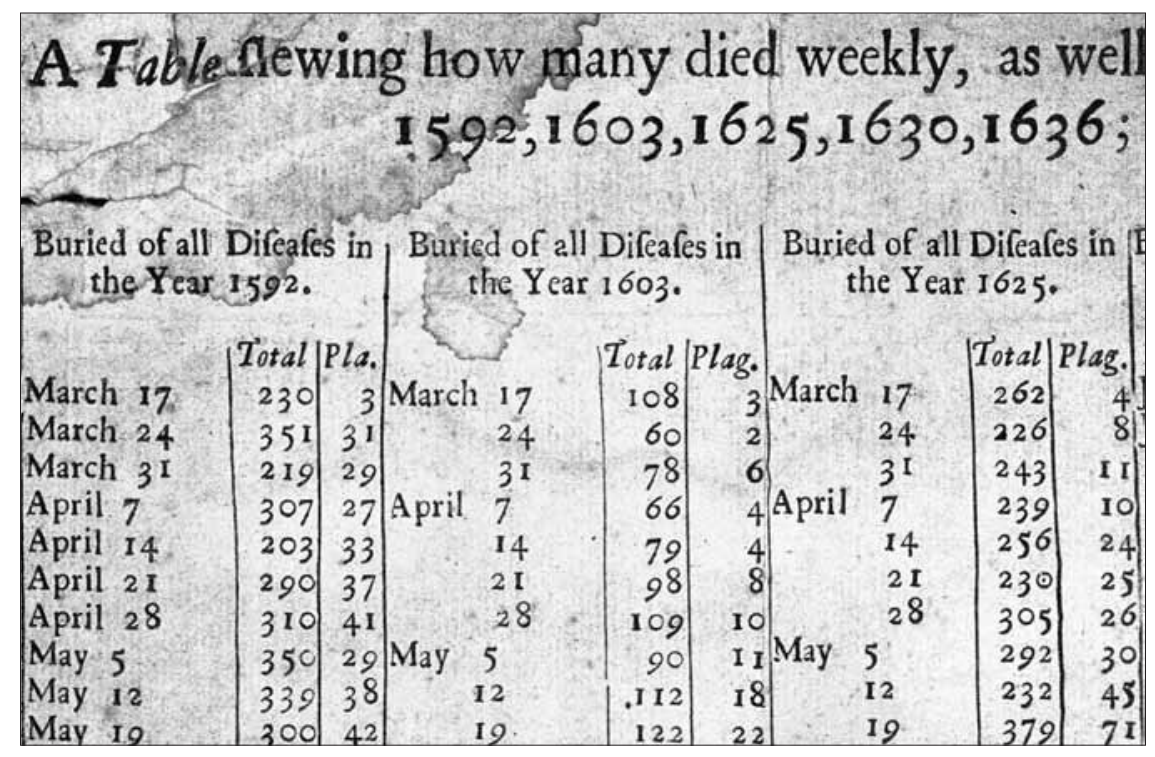

Figure 1. Detail of a bill of mortality, London, 1665. Letterpress. The complete broadside $275 \mathrm{x}$ $245 \mathrm{~mm}$.

compared with printed books, that it is pointless to attempt any quantitative comparisons of these categories of work based on surviving examples. Nevertheless, estimates made by economic historians (with no agenda to minimize the significance of the book) provide us with broad indicators of the relative importance of various branches of the printing industry in the nineteenth and twentieth centuries. My examples come from Britain, though I feel certain that a similar picture would emerge in the United States if appropriate data existed and could be analyzed.

Some forty years ago the British economic historian B.W.E. Alford, working from business records and extrapolating from the limited data available, came up with the following figures for the London letterpress printing trade in the mid-nineteenth century. ${ }^{7}$ For the year 1831, he estimated that expenditure on book and periodical printing was $£ 120,000$, on government printing $£ 160,000$, and on jobbing printing $£ 120,000$ (the same as for book and periodical printing). Twenty years later, in 1851 , according to his estimates, expenditure on book and periodical printing was $£ 400,000$, on government printing $£ 230,000$, and on jobbing printing the relatively smaller sum of $£ 170,000$. We have to remember, however, that London dominated the book and periodical market in Britain, and that in this period all but a few of the largest printing firms were located in the capital. Numerous smaller firms located in the provinces - which were excluded from Alford's survey-would almost certainly have concentrated on jobbing work. Furthermore, Alford's calcula-

7. B.W.E. Alford, "Government Expenditure and the Growth of the Printing Industry in the Nineteenth Century,” Economic History Review, 17:1-2 (1964-65): 97. 
tions were based on letterpress printing and took no account whatsoever of the growing lithographic trade, which undertook next to no book production in Britain at the time. ${ }^{8}$ We can assume, therefore, that jobbing printing in Britain as a whole represented a significantly greater proportion of total expenditure on printing than even Alford's figures suggest.

Comparisons of sectors of the printing industry in the middle of the following century are even more revealing. Data gleaned from the 1950s for an economic study of the British printing industry that was published in 1965 reveal just how small the proportion of book printing was in relation to other branches of the industry. ${ }^{9}$ In 1954, measured by sales, books accounted for just under $£ 22$ million of a total expenditure on printing of over $£ 430$ million (that is, around 5 percent of the total).$^{10}$ Measured by employment, book production in 1854 accounted for fewer than 17,000 out of a total of over 265,000 workers (or approximately 7 percent of the total). ${ }^{11}$ Even though it is difficult to establish the precise meaning of the categories of printing for which figures were given in this survey (that is, books, periodicals, cartons, and stationery), it is surely relevant to my argument that on both these measures the figures for printed stationery alone were far greater than those for books. These two economic assessments of the printing trade confirm in a general way the impression one gets when immersed in printed ephemera of the nineteenth and twentieth centuries.

The argument I shall be making is that to neglect ephemera, which accounted for one of the largest sectors of the British printing industry in this period-and I believe the same to be true in the United States - is both to distort the history of the printing trade and to underestimate significantly its impact on society. And when book historians remark on the scarcity of books stemming from the presses of known book printers and wonder how they made a living, the answer is almost certainly that they printed ephemera (as part, that is, of their general portfolio of trades).

I shall refer only very briefly to the significance of the content of printed ephemera. Historians of many kinds_-social, cultural, and business—now recognize their

8. For the growth of the lithographic trade in London in this period, see M. Twyman, A Directory of London Lithographic Printers 1800-1850 (London: Printing Historical Society, 1976). The relative paucity of books printed by lithography before machine production is evident from the same author's Early Lithographed Books (London: Farrand Press and Private Libraries Association, 1990), which lists only 423 such items, many of them from outside Britain. Subsequent research has revealed around 150 further books produced by similar means in the nineteenth century.

9. The British Federation of Master Printers, Economic Study of the Printing Industry (London: BFMP, May 1965). The figures I give have been rounded up or down from data shown in table 3 of the publication.

10. Ibid. The figures I give have been rounded up or down from data shown in table 4 of the publication.

11. Ibid. The data are taken from tables 3 and 4 . In 1954 the spend on stationery was $£ 44.4$ million, on books $£ 21.9$ million; in the same year the figure provided for employment on stationery was 25,500 , on books 16,700 . 


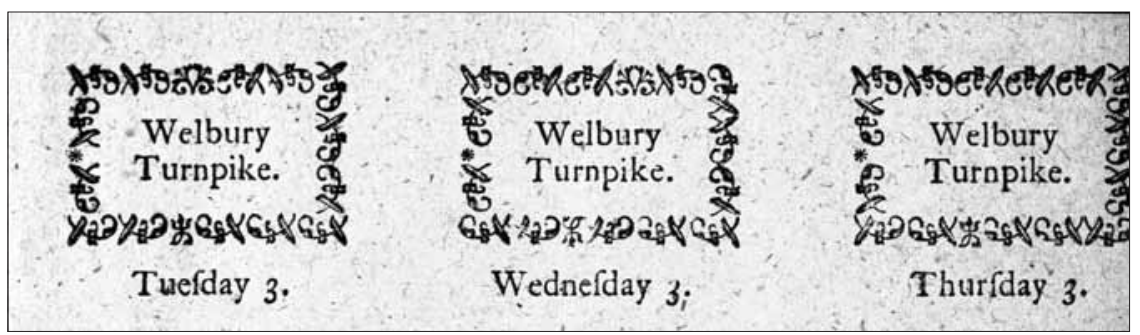

Figure 2. Detail of a sheet of thirty-five turnpike tickets, ca. 1800. Letterpress. The complete sheet $265 \times 325 \mathrm{~mm}$.

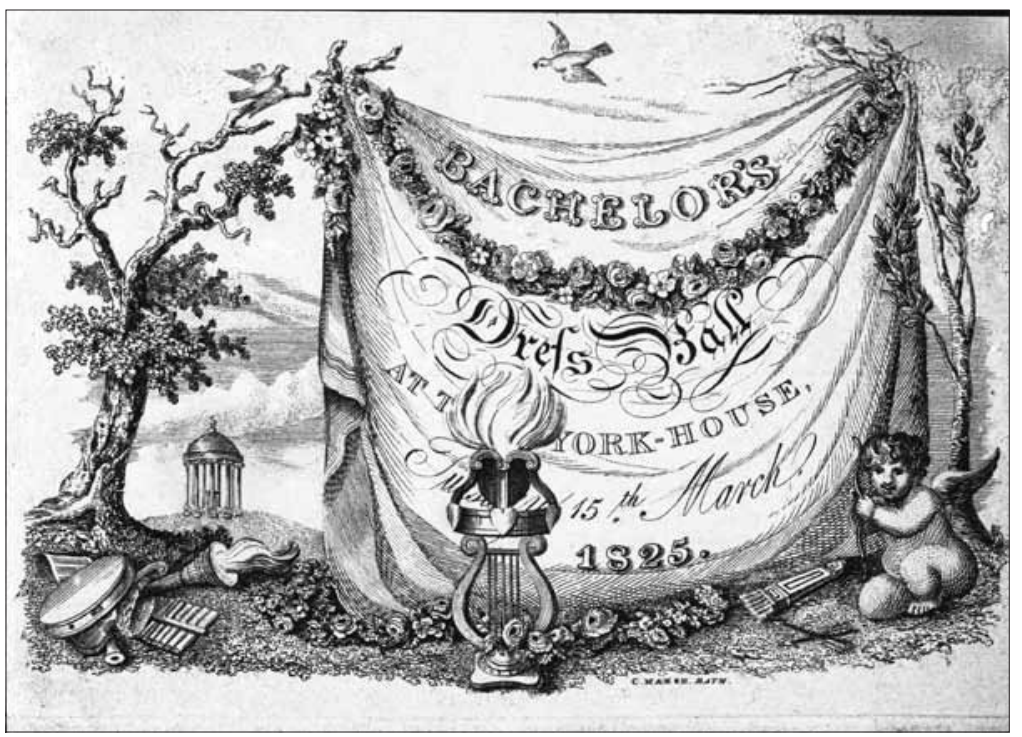

Figure 3. Invitation to a bachelor's dress ball, 15 March 1825. Intaglio printed. 86 x 120 mm.

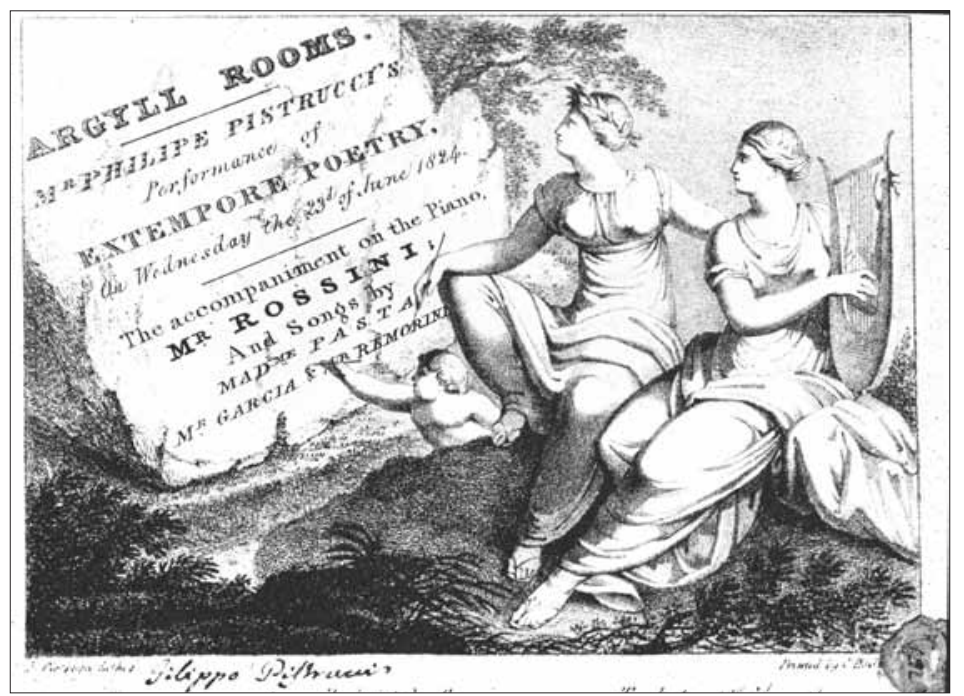

Figure 4. Invitation to a performance of "Extempore poetry," 23 June 1824 in the Argyll Rooms, London. Lithography. Printed by Charles Hullmandel. 
value as source material. After all, every item of ephemera tells a story, or at the very least reveals specific information about something. This may amount to no more than that a toll gate existed at a particular place (figure 2) or that someone held a ball in their country house on this or that date (figure 3). But other items tell us of more bizarre things, such as an invitation to a performance of extemporary poetry, accompanied on the piano by no less a person than Rossini, in the Argyll Rooms, London, in 1824 (figure 4).

Items of ephemera that relate to advertising provide particularly fascinating glimpses of the past, as seen in a lithographed notice of a lakeside property that was to let or for sale around 1824 at Enghien-les-Bains, just outside Paris, with its unusual description for the time in the form of words, a view, and plan (figure 5). It is the examination of pieces of ephemera in relation to their context (it we can get to know about it) that makes sense of what they tell us and helps to bring them to life. Figure 6 illustrates a notice about a procession to celebrate the opening of a brand-new local hospital in 1839, the Royal Berkshire Hospital in Reading, the town where I have worked all my life. The original hospital building still survives, and parts of it are literally within fifty yards of where I used to work. I am no expert on the history of the hospital, but I have spent a little time searching for other information about this occasion and, in particular, of

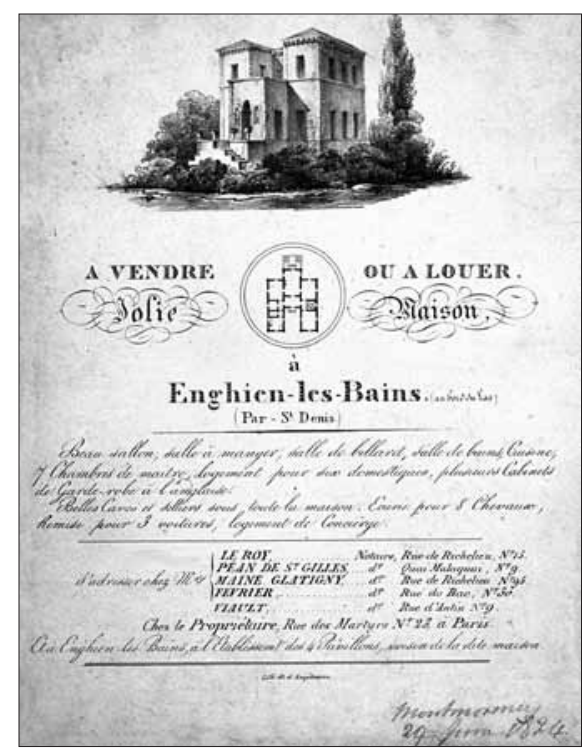

Figure 5. Notice of a house for sale or rent at Enghien-les-Bains, France. Lithographed by Godefroy Engelmann in Paris, ca. 1824. 270 × 205 mm.

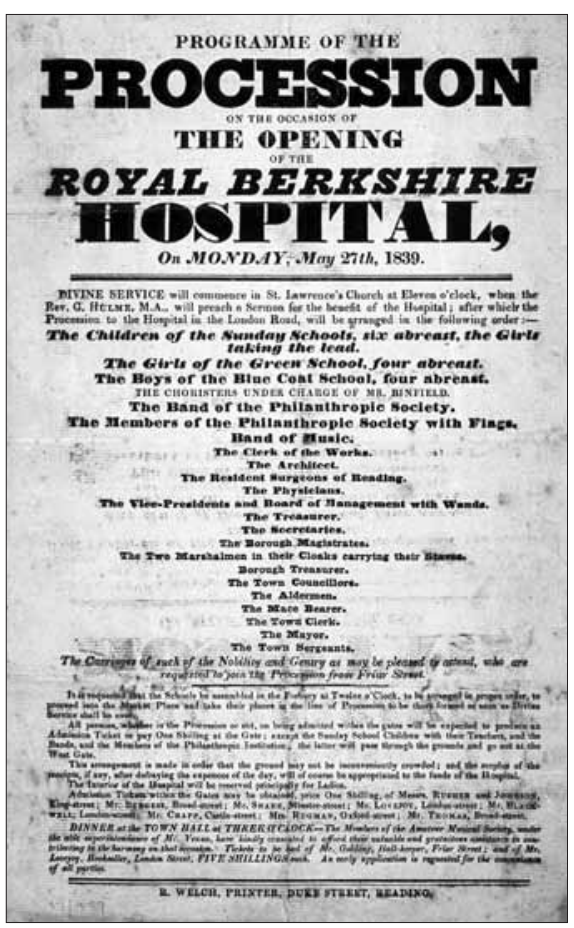

Figure 6. Program of a procession to celebrate the opening of the Royal Berkshire Hospital, 27 May 1839. Letterpress. Printed by R. Welch, Reading. 315 x 196 mm. 


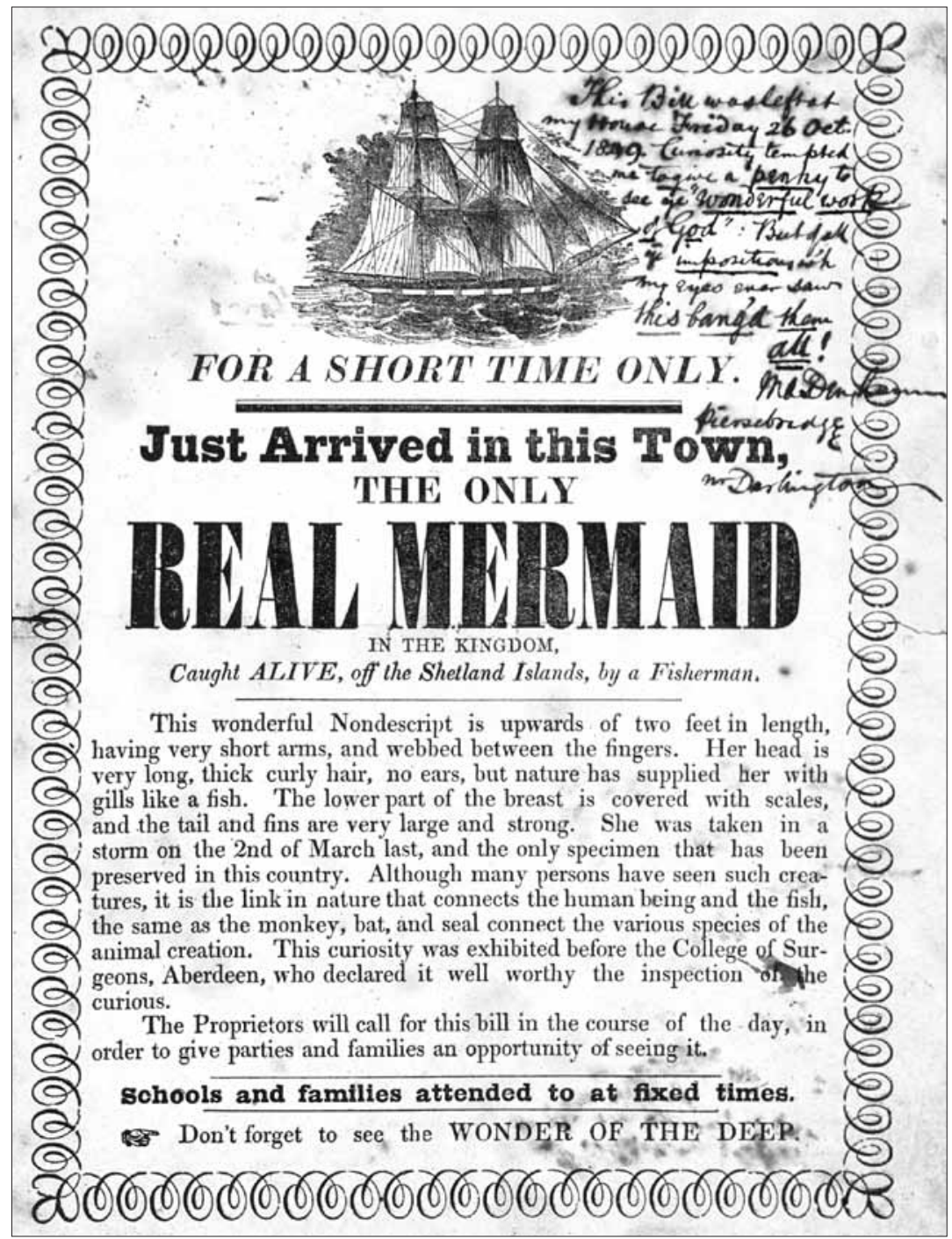

Figure 7. Notice of the exhibition of a "Real mermaid." Letterpress. With a manuscript observation revealing that it was left at the owner's house, near Darlington, 26 October 1849. $253 \mathrm{x}$ $190 \mathrm{~mm}$.

the procession and other arrangements for the day described on this notice. Both local papers, the Berkshire Chronicle and Reading Mercury, included lengthy accounts of the day, ${ }^{12}$ but nothing I could find on their pages was quite so specific as this notice about the participants and the ticketing arrangements, nor so evocative of the occasion. Like other ephemera that record events, this notice tells only part of a story, but it is a part that might otherwise not have been told.

12. Berkshire Chronicle, vol. 15, no. 743 (Saturday, 25 May 1839), and no. 744 (Saturday, 1 June 1839); Reading Mercury, Oxford Gazette, Newbury Herald, and Berks County Newspaper, vol. 117 (Saturdays 11 May, 18 May, 25 May, and 1 June 1839). 
Sometimes, though not as often as we would like, ephemera tell us something even more specific, as does one rather timeworn example from the mid-nineteenth century (figure 7): an announcement of the appearance in public of a mermaid—in this case, not of any old mermaid, but of a real one. The notice falls into a coherent category of ephemera concerned with freaks (bearded ladies, giants, strong men, monsters, and so on). I imagine that we are inclined to regard advertising of this kind as evidence of the naïveté of past generations (though we have our equivalents today, of course). But this particular piece of ephemera, with its manuscript observation, reminds us that there were skeptics even at that time. It was kept, one supposes, as a souvenir of the spectacle, and records a visitor's reactions to the occasion in its top right-hand corner:

This Bill was left at my House Friday 26 Oct. 1849. Curiosity tempted me to give a penny to see ye 'wonderful work of God'. But of all ye imposition w'h my eyes ever saw this bang'd them all!

[signed] M Denham of Piersebridge nr Darlington.

Not only does the poster tell us about the event itself, but it captures an individual's response to what he or she saw, revealing, as it happens, evidence of the practice of house-to-house distribution of bills, and an insight into the vernacular language of the day of a kind that may well not have found its way into print.

One immensely informative category of ephemera relates to trade and includes catalogues, price lists, trade cards, billheads, invoices, and receipts. Without such items we would know very little in particular about the range of products and services available at a given time and place. Even when the actual products still exist somewhere, trade ephemera, especially catalogues and price lists, help to put them into a more general context. Numerous trade catalogues and price lists survive scattered among collections of ephemera, though one suspects many do so in very few copies, while others must be unique.

A single-leaf catalogue of 1829 , with prices of a Bavarian supplier of fruit and decorative trees, is just such an item

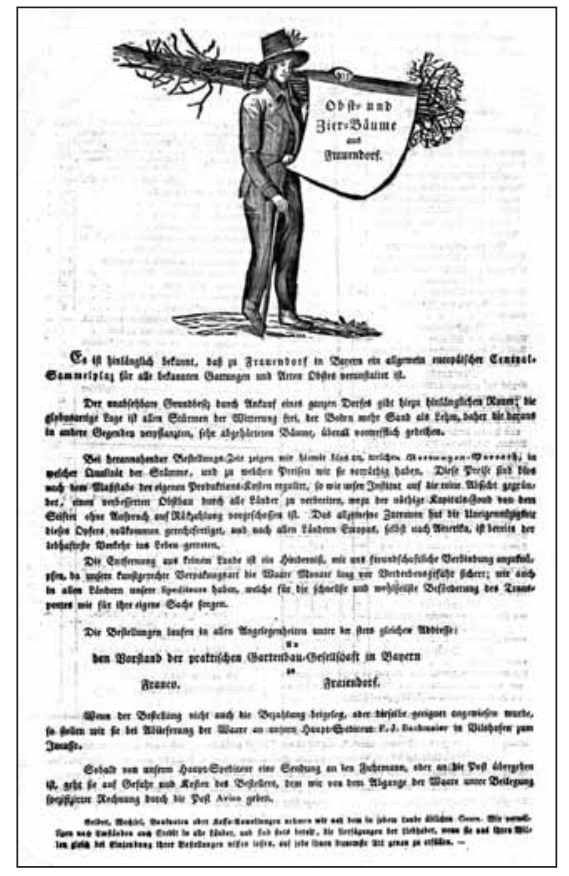

Figure 8. Single leaf catalogue of a supplier of fruit and decorative trees in Frauendorf, Bavaria. Letterpress with woodcut, 1829. $385 \times 250 \mathrm{~mm}$. 
(figure 8). Not only does the supplier provide a fine range of plants, with prices, but he offered them for sale in the United States and included in his advertising spin what I suspect is a very early version of the well-known adage "a good
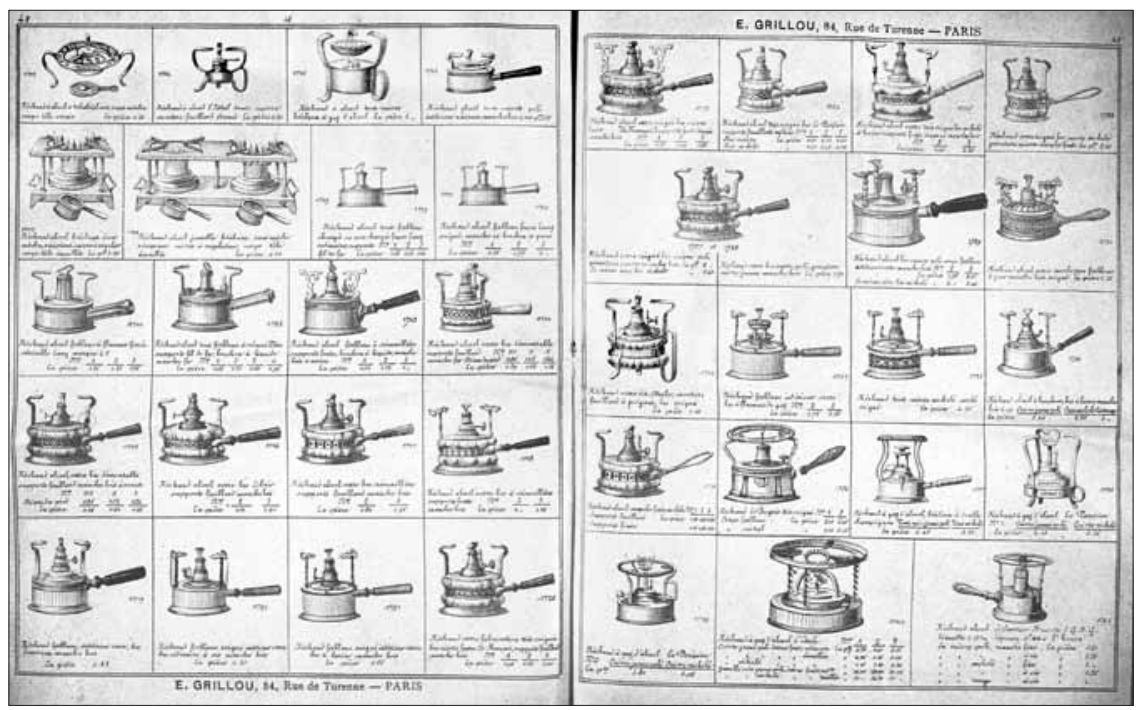

Figure 9. Double-page spread from a catalogue of E. Grillou, manufacturer of ironmongery, Paris, 1903. Lithographed: drawn and written on transfer paper. Page size $270 \times 210 \mathrm{~mm}$.

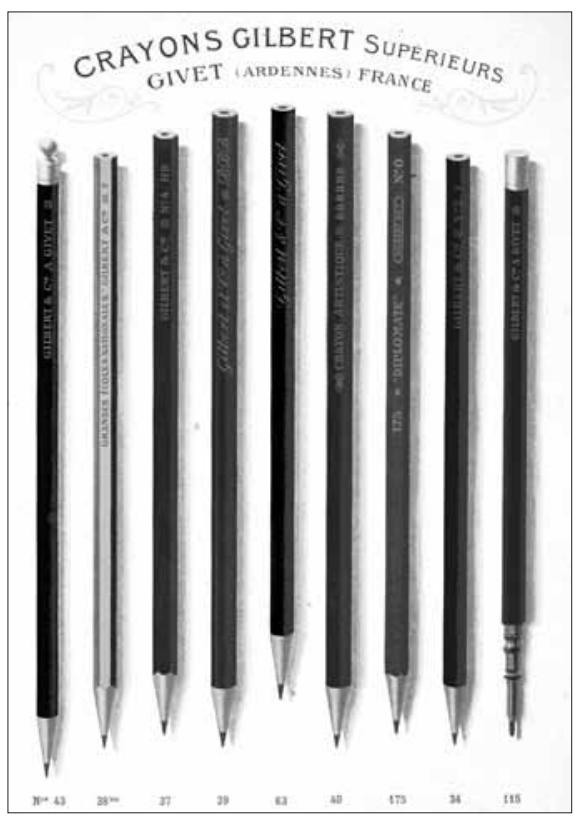

Figure 10. Color plate from a catalogue of the pencil manufacturer Gilbert et Cie, Givet (Ardennes), c. 1905. Chromolithographed in eight colors by A. Waton, St. Etienne. Page size $268 \times 210 \mathrm{~mm}$.

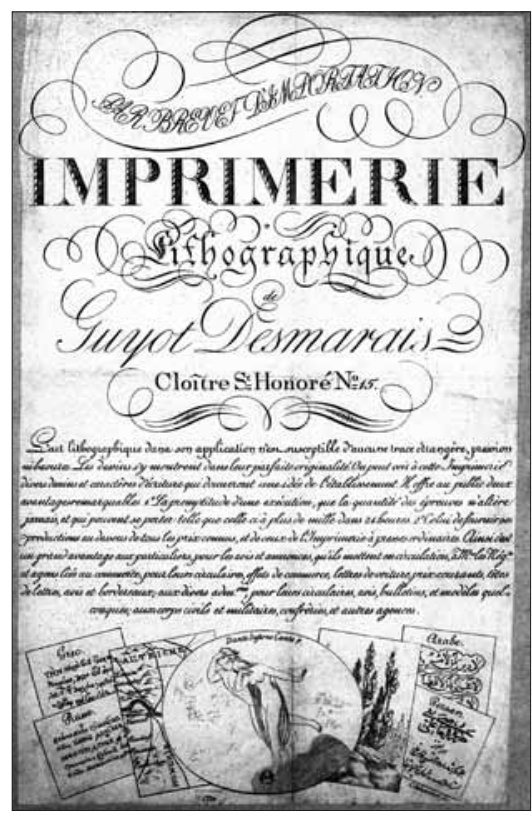

Figure 11. Advertisement of the lithographic printer Guyot-Desmarais in Paris, ca. 1809. Drawn by C. Johannot. Lithographed. Printed image 485 x $310 \mathrm{~mm}$. 
product advertises itself." A modest but more comprehensive catalogue provides a further example. It relates to a manufacturing ironmonger in Paris, E. Grillou, which was founded in 1890 and, from time to time, issued catalogues. Dated 1 May 1903, it includes descriptions of 2,631 items, most of them illustrated. The spirit stoves shown on one double spread (figure 9) suggest that the consumer of the day was as spoilt for choice as we are 100 years later with our electronic gadgets. And where else could one go to find a range of information about the kinds of spirit stoves available in the early twentieth century?

Other catalogues manage to turn ordinary objects into things of beauty, whether brushes, thermometers, or pencils, as in the French chromolithographed catalogue printed in St. Etienne at the beginning of the twentieth century, reproduced here (figure 10). If we turn to ephemera that relate to the printing trade - which, as you will understand, I have a particular interest in —we occasionally discover items that reveal things we would probably not otherwise know about, or provide clear evidence for products that are referred to only in general terms elsewhere. I shall select two examples from my own specialist field of lithographic printing, because I can speak with a little understanding of the insights they have provided for me. The first is a trade card of a very early lithographic printer in Paris, Guyot Desmarais (figure 11). We know very little about him, except that he was a painter who turned his hand to lithography about 1809 and produced a large trade card soon afterwards, which is now in the Bibliothèque nationale de France..$^{13}$ The latest edition of Bénézit’s standard dictionary of artists suggests that there is some doubt about the man's name. In a very short entry he is listed as "Guyot or Guyton Desmarais": ${ }^{14}$ yet this piece of ephemera, the trade card issued by the man himself, surely provides clarification of his actual name.

Unusually, in a period when others were exploring the new process for its artistic potential, Desmarais also drew attention to its possibilities as an alternative to letterpress printing for jobbing work, or, as we might say, "printed ephemera," showing examples at the foot of the card that point to its convenience and economy for work in Greek, Cyrillic, Arabic, and Farsi, which would have presented problems for most letterpress printers. In the paragraph of text he boasts that he was capable of turning out around 1,000 copies of a document in just twenty-four hours. ${ }^{15} \mathrm{In}$

13. Bibliothèque nationale de France, Département des Estampes et de la Photographie, Ad. 64a. t.1.

14. E. Bénézit, Dictionnaire critique et documentaire des peintres, sculpteurs, dessinateurs et graveurs (Paris: Gründ, 1999).

15. "Il offre au public deux avantages remarquables. $1^{\circ}$ La promptitude d'une exécution, que la quantité des épreuves n'altère jamais, et qui peuvent se porter telle que celle ci à plus de mille dans 24 heures. $2^{\circ}$ Celui de fournir ses productions au dessous de tous les prix connus et de ceux de l'Imprimerie à presses ordinaries." [It offers the public two notable advantages. 1. Speed of production, which is not affected by the number of impressions taken, and which can be carried out, as here, at more than a thousand impressions in 24 hours. 2. That of producing material at rates lower than any others known and than ordinary letterpress printing.] 


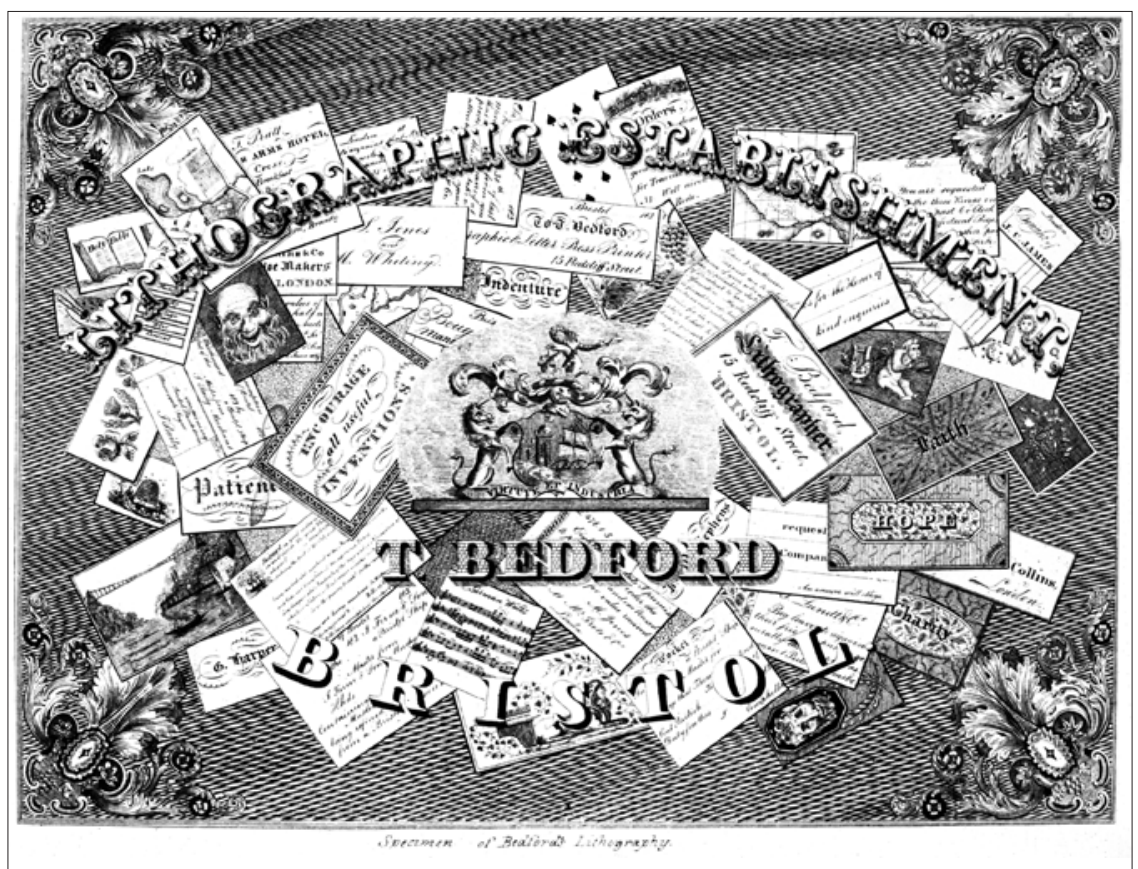

Figure 12. Trade card of the Bristol lithographer T. Bedford of the 1830s showing a range of jobbing work. Lithographed. Printed image 150 × $199 \mathrm{~mm}$.

effect, his press was the precursor of our high-street copying shops, and he and others pointed the way for an explosion of lithographic jobbing printing a few decades later, though rather more so in Europe, it seems, than in the United States.

My second example is a trade card of a British provincial lithographer some twenty years later, around 1830 (figure 12), by which time the lithographic trade had established itself in many parts of Europe and was responsible for a great deal of jobbing or ephemeral printing. The printer concerned, T. Bedford of Bristol, chose to illustrate a medley of examples of ephemera he produced, or perhaps hoped to persuade potential clients to commission from him. Examined carefully, the card reveals something of the wide range of monochrome ephemera that this particular printer regarded as suited to lithography in the 1830s. Numerous cards of this kind, issued by printers in Europe and the United States, reinforce this point. Were it not for the content of trade cards and advertisements such as these, we would know very little about the range of lithographic ephemera produced and therefore what to look out for and where to go to find it.

The case for the long-lasting significance of ephemera by virtue of their content is, I imagine, self-evident and needs no further example or comment. I suspect, however, that it may be necessary to make a case for the significance of ephemera as documents with their own textual, graphic, and artifactual characteristics, and 
this will be the focus of the rest of this article. It would be helpful to have a word to describe the study of such documents, if only to stress the distinctiveness of this particular category of printing; and I tentatively offer the term "ephemerology" to define a parallel branch of knowledge or study comparable to bibliography, cartography, and musicology (in its graphic aspects).

The most visible contribution made to print culture by ephemera was the introduction of bold and arresting typefaces of the kind used for a little posting bill of 1826 from Ulverston in the north of England (figure 13). ${ }^{16}$ This is not the place to go into the origins of such types, ${ }^{17}$ but already, by the end of the eighteenth century, printers of London theater bills had begun to use large letterforms on their posters to attract attention, occasionally printing them in red. A decade or so later, the agents for British lotteries, usually working on a smaller scale, introduced decorated woodcut letters on their advertising bills for similar reasons, as seen in an example from 1810 (figure 14). The designs of these letters took entirely new forms and provided models that all the important British type-founders of the 1820 s began to emulate. There followed a profusion (some would say "plethora") of new typefaces in the specimen books issued by type-founders, including the appropriately named fat face (figure 15), the Antique or Egyptian (figure 16), the shaded (figure 17) —all redolent of the period in their choice of words - and the

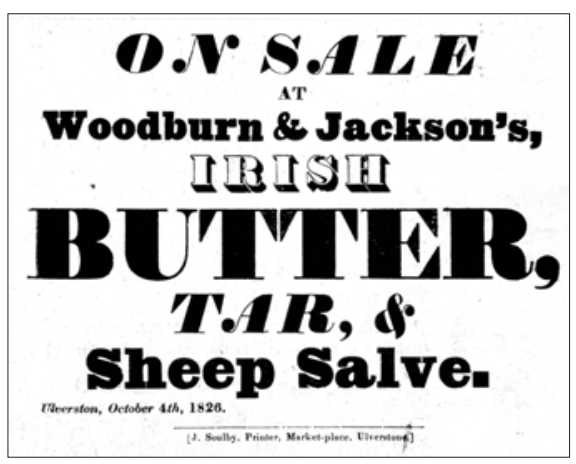

Figure 13. Advertising bill, Ulverston, 1826. Letterpress. Printed by John Soulby Junior. 200 x $245 \mathrm{~mm}$.

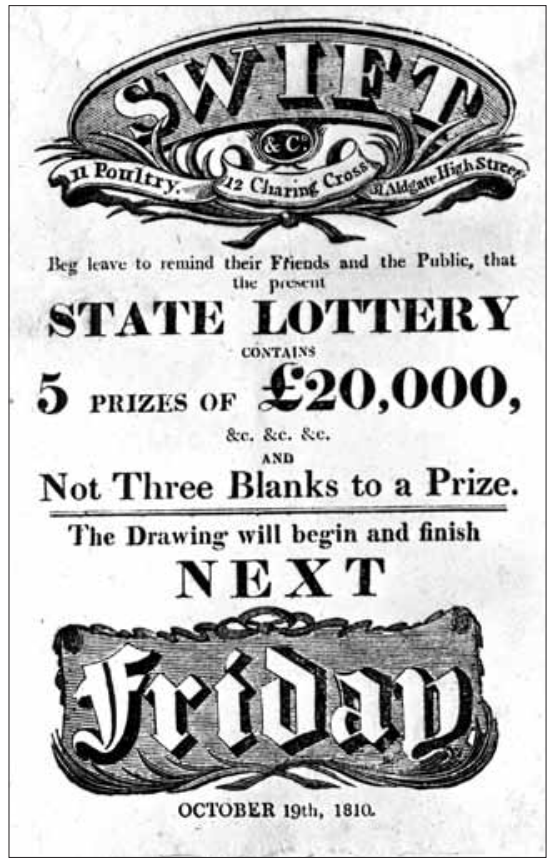

Figure 14. Swift \& Co., lottery bill for 18 October 1810. Letterpress with wood-engraved lettering at head and foot. $222 \times 140 \mathrm{~mm}$.

16. For a discussion of the work of this printer, see M. Twyman, John Soulby, Printer, Ulverston (Reading: Museum of English Rural Life, 1966).

17. The standard work on British display types is N. Gray, Nineteenth Century Ornamented Typefaces (London: Faber \& Faber, 1976), which was originally published as XIXth Century Ornamented Types and Title Pages (London, 1938); and on American ones, Rob Roy Kelly, American Wood Type 1828-1900 (New York, 1969; reprinted Da Capo Press, 1977). 
perverse Italian (figure 18) (a term that may have been considered abusive enough to encourage Italians to get back by referring to it as "Americano"). And later there were decorated types (figure 19) and bold sans serifs (figure 20). All these types

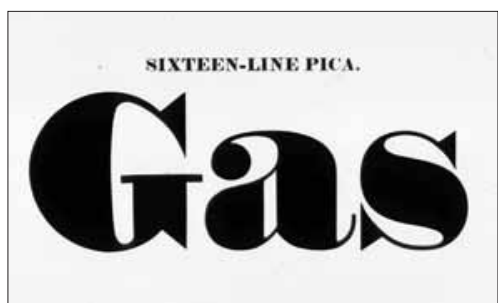

Figure 15. Fat-face types, from Caslon \& Livermore, Specimen of Printing Types, London, 1825.

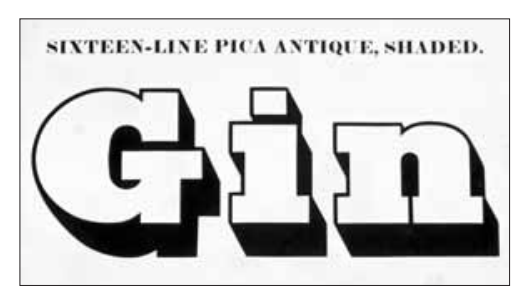

Figure 17. Shaded types, from Caslon \& Livermore, Specimen of Printing Types, London, n.d.

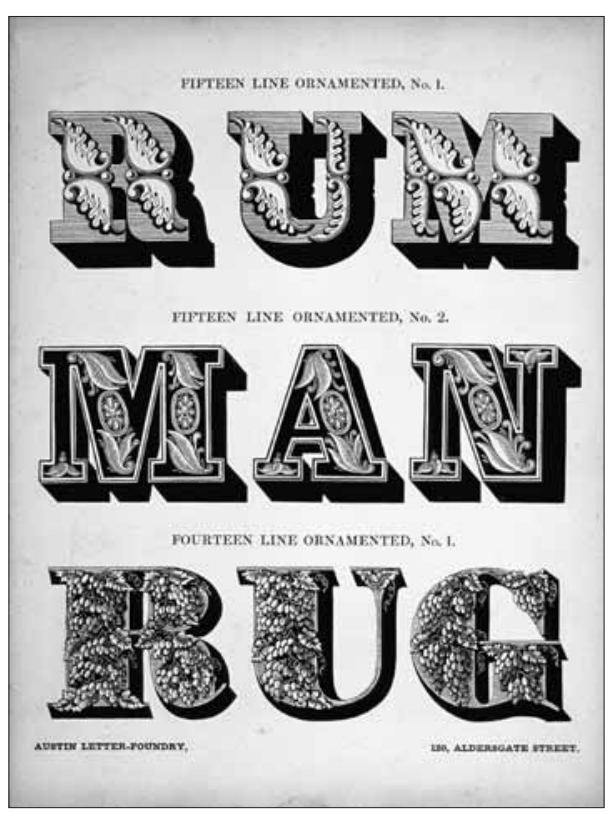

Figure 19. Decorated types, from Wood \& Sharwoods, The Specimen Book of Types Cast at the Austin Foundry, London, ca. 1844.

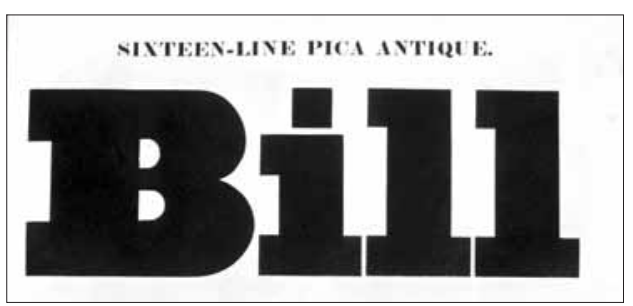

Figure 16. Egyptian types, called here "Antique," from Caslon \& Livermore, Specimen of Printing Types, London, n.d.

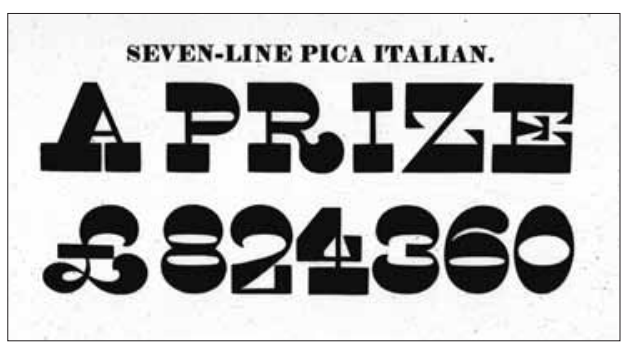

Figure 18. Italian types, from Caslon \& Livermore, Specimen of Printing Types, London, 1825.

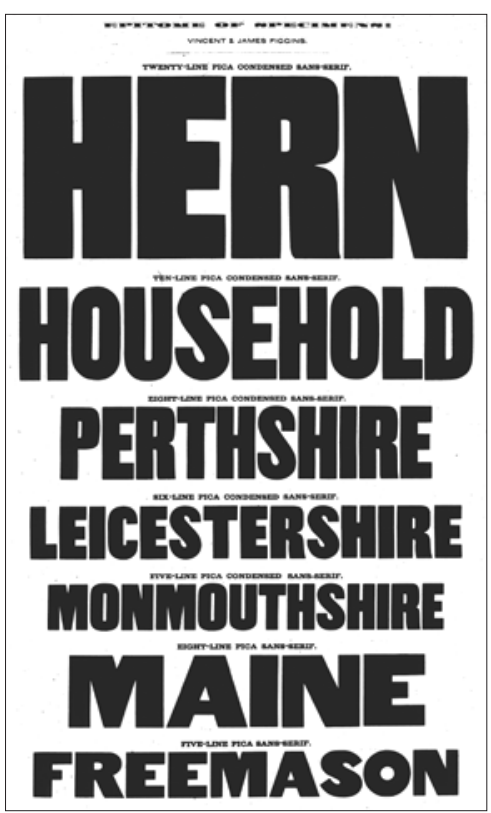

Figure 20. Bold sans serif types, from W. Thorowgood \& Co., A General Specimen of Printing Types, London, 1848. 
were taken up right across the country, often within a few years of their first appearance in the capital.

The most effective of all, because it allowed for the greatest concentration of ink within a given area, was the slab serif, or Egyptian letter. But all these typefaces - and the United States had its equivalents not long afterwardwere used to attract attention on notices and posters. William Savage, printer to the Royal Institution, writing in his Practical Hints on Decorative Printing (London, 1822), refers to them as "giving a bold effect to particular words intended to strike the eye and attract the attention of the reader and the passenger in the streets." ${ }^{18}$ As the century progressed, these designs became more and more exotic, and some were produced as large as eighteen or so inches high.

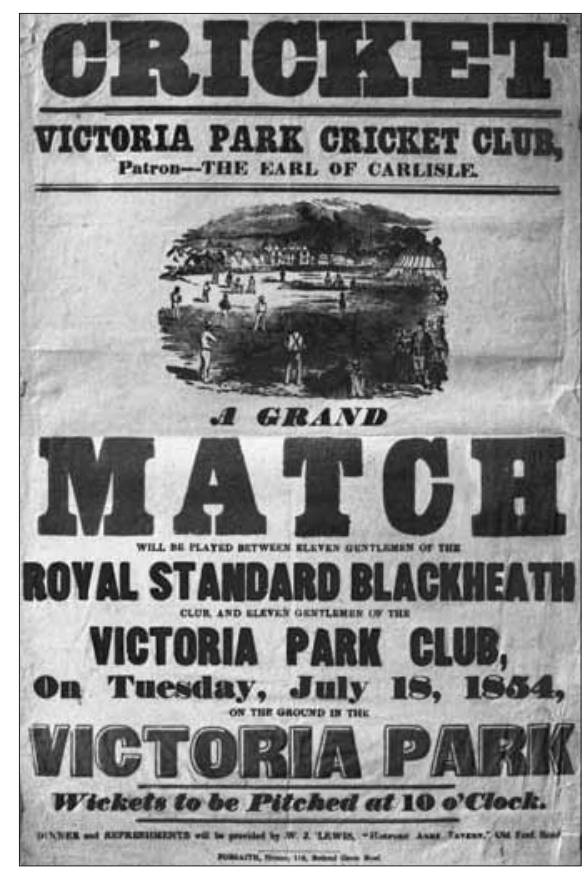

Figure 21. Notice of a cricket match, Victoria Park, London, 18 July 1854. Letterpress, with wood-engraving, printed in red and blue by Forsaith, London. $380 \times 253 \mathrm{~mm}$.

Needless to say, such typefaces, even versions in small sizes, found next to no place in books, and in the same publication Savage specifically warned against their use for such purposes. ${ }^{19}$ In any event, large display types are to be found almost exclusively in ephemera, and particularly public notices and advertising, as on a poster for a cricket match in 1854 (figure 21). These types even affected typography in France, where the Neo-classical Didot tradition was so strong, as we can see when we compare two theater bills printed in Orléans for the same theater in the 1820 s. The earlier example (figure 22), printed in 1824, is in the prevailing Didot style of typography; but within a few years, in 1827, the same printing house, under new ownership and with a new kit of fat-face type, changed its approach radically (figure 23).

The introduction of such display types led to what I believe to have been one of the most significant developments in print culture before the electronic revolution of the last few decades. It is best illustrated and described by showing an unusual

18. Savage, Practical Hints on Decorative Printing (London, 1822), 21.

19. Ibid., 21, 74 . 


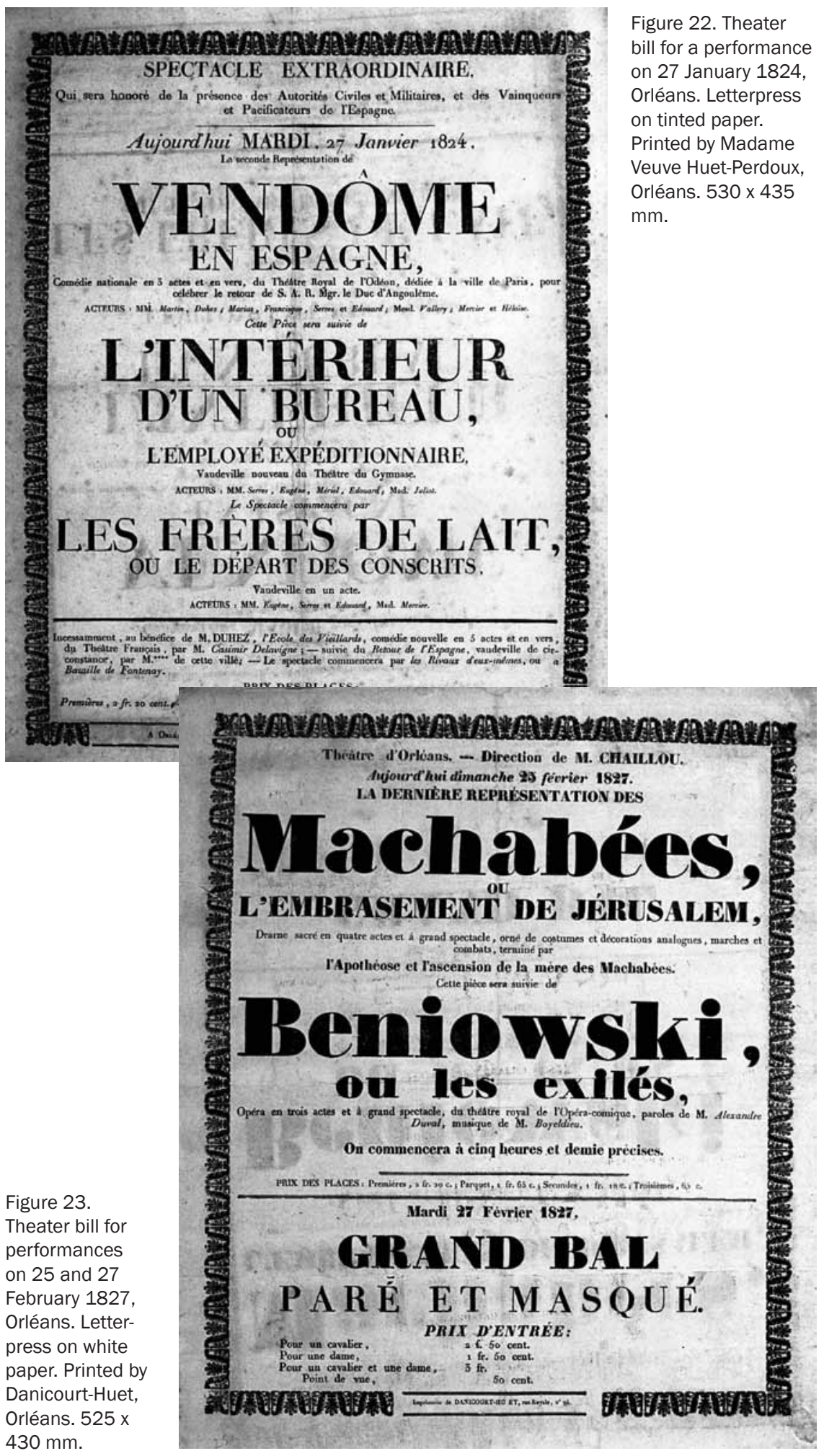


poster which was printed in Bath in the early nineteenth century (figure 24). Its printer, Frederick Gye, was one of a dynasty of jobbing printers, his successors producing some remarkable work in London in the second quarter of the century, particularly for Vauxhall Pleasure Gardens. ${ }^{20}$ In this poster from around 1810, Gye plays with his readers, inviting them to read the message on two levels. Most obviously, Gye's contemporaries would first have read the words "Pleasure without fatigue" - as I imagine present-day readers would do. Then, if they had been sufficiently attracted by this delightful thought, they might have read the message in a strictly linear fashion, line by line, from the top of the sheet downwards.

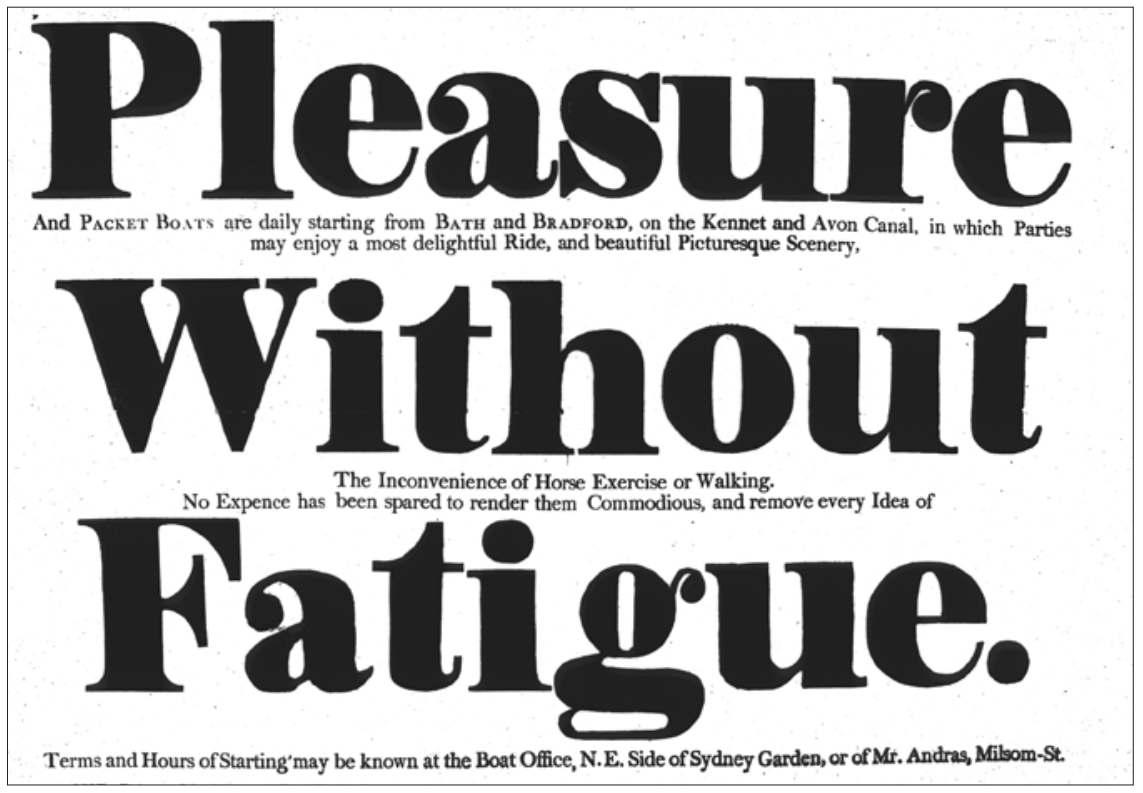

Figure 24. Packet-boat notice for the newly opened Kennet \& Avon canal, England. Letterpress, the large letters cut on wood. Printed by Gye in Bath, ca. 1810. 450 x 640 mm.

Gye may not have been the very first to adopt an approach of this kind, which virtually forces readers to abandon their normal reading strategies. All I can claim is that it is the first example of it that I have seen. Even though plagiarism was rife at the time, if others had tried to do something similar in an earlier period they would have been hampered by the lack of large arresting display types, which were an essential ingredient of a poster if this telegraphic approach was to work effectively. Within decades, however, the general idea underlying the organization of language in Gye's poster became commonplace in a wide range of letterpress posters. It offered the possibility of reading a text in two ways: through selected words printed

20. For Gye and his successors, see R. Banham, "Frederick Gye and Giles Balne: A Study of the Firms Gye \& Balne (1805-1829) and Balne (1829-1838) with Particular Reference to their Colour Printing," PhD diss., The University of Reading, 2004. 


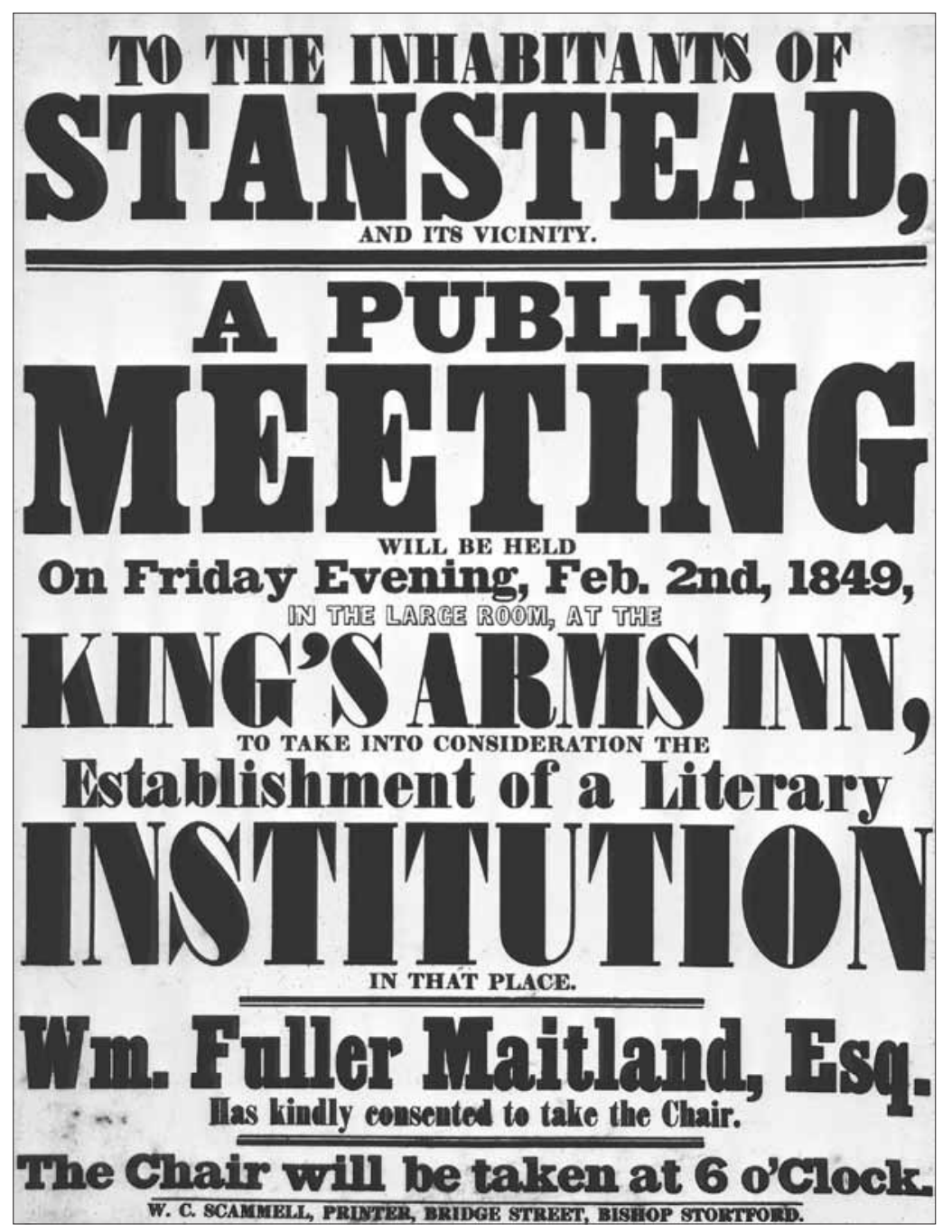

Figure 25. Notice of a meeting in Stansted [then Stanstead] to consider the establishment of a literary institution, 1849. Letterpress. Printed by W. C. Scammell, Bishop's Stortford. 430 x 344 mm.

in bold, and also, slightly less coherently in the case of this Gye poster, from head to foot in a single sequence.

The conventional approach in British letterpress posters of the nineteenth century was less ingenious linguistically than Gye’s, but just as effective graphically. ${ }^{21}$ It involved picking out individual words or lines of copy in large, bold type, according to their assumed significance to a message, and allowing all the rest to recede

21. Many examples can be found in J. Lewis, Printed Ephemera (Ipswich: W.S. Cowell, 1964), M. Rickards, Collecting Printed Ephemera (Oxford: Phaidon/Christie's, 1985), and M. Twyman, Printing 1770-1970: an Illustrated History of its Development and Uses in England (London: Eyre \& Spottiswoode, 1970; reprinted The British Library, 1998). 
by using much smaller sizes of type. The approach was as widespread in America as it was in England. In a mid-nineteenth-century poster (figure 25), printed in the small town of Stanstead (now known as Stansted - the site of one of London's airports), we read a few keywords, even though the substance of the message runs as a single sentence. This is clear if we read the text out loud or listen to someone else doing so. After the heading: "To the inhabitants of Stanstead, and its vicinity" the text reads:

A public meeting will be held on Friday evening Feb. 2nd, 1849 in the large room at the King's Arms Inn, to take into consideration the establishment of a literary Institution in that place. Wm Fuller Maitland has kindly consented to take the chair.

It is not for anyone alive today to say how the good people of Stanstead would have read this poster in the mid-nineteenth century, but I hazard a guess that no one here would have read it initially in a linear manner. That is partly because some of the type is too small, and partly because, like the "passengers in the streets" in Stanstead in 1849 , we may not have the time to do so. I suspect, however, that even if these two conditions had been satisfied, it is likely that we would have read the following first of all: "Stanstead"/ "meeting" (possibly "public meeting") / "King's Arms Inn" / and "Institution." This poster was intended for distance reading of the kind demanded when projected as a slide in an auditorium. In its intended context, it might usefully be called "street reading" for-to use William Savage's term— "the passenger in the streets." And this is clearly very different from the more contemplative kind of reading done with book in hand. ${ }^{22}$

The significance of street reading, even in the early nineteenth century, can be judged by the appearance of "stick no bills" notices in paintings and prints, as in an 1815 watercolor drawing of Clare Market, London, where one can see such a notice to the left of a group of fly-posted bills! $!^{23}$ In France, detailed legislation relating to the display of posters on buildings, some of it dating from as far back as the late eighteenth century, underlines how widespread this kind of reading was there, too. ${ }^{24}$ Further evidence of the importance of street reading is provided by a photograph by William Henry Fox Talbot, who recorded Nelson's Column in the course

22. Diane DeBlois has been kind enough to draw my attention to a discussion of similar issues in D.M. Henkin's City Reading: Written Words and Public Spaces in Antebellum New York (New York: Columbia University Press, 1998).

23. George Shepherd, "Clare Market," in the Guildhall Library, London (reproduced in J. F. C. Phillips, Shepherd's London [London: Cassell, 1976], plate 11).

24. See, for example, Perrève and Cochet de Savigny, Formulaire général et annoté à l'usage de tous les militaires de la Gendarmerie départmentale et de la Garde municipale de Paris, 2nd ed. (Paris: Léautey, 1844), 118-19, 257-58, 394-47. 
of construction in 1844, with its base surrounded by protective boards plastered with printed posters. $^{25}$

Street reading required that a message be taken in both at a distance and also at a glance. It would surely have been an exceptional person who would have stopped to read the circus posters of the early 1840 s reproduced here as linear strings of words running from top to bottom (figure 26). It could also be argued that such posters, with their telegraphic approach to design that involved flagging up a few keywords, catered for the needs of a growing semiliterate public, which would at least have been able to take in the gist of a message from just a few words. But whatever the reason for this innovation in printing —or, as I would refer to it, this new approach to design for reading - it was first made in ephemera in the early nineteenth century and became the norm for British letterpress posters on into the twentieth century, as it did in the United States. Today it survives in modified forms in advertising, but finds its most obvious expression in the tabloid press. We see pale echoes of it in textbook

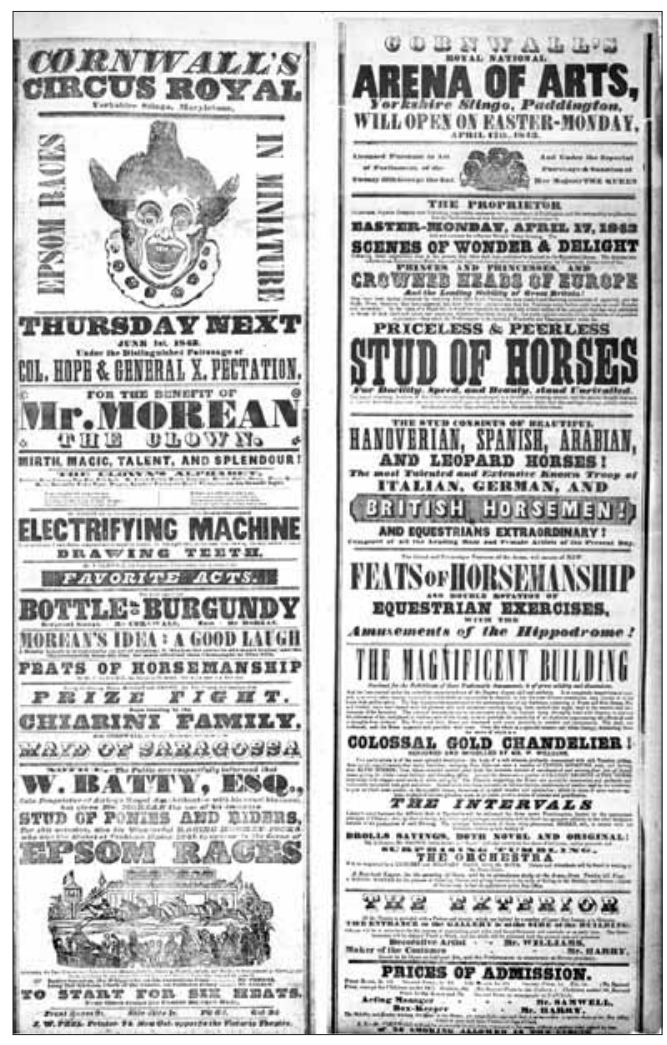

Figure 26. Two circus posters, 1843. Letterpress, on the left in blue, on the right in red and blue. Printed by J. W. Peel, London. Each approximately $750 \times 240$ mm.

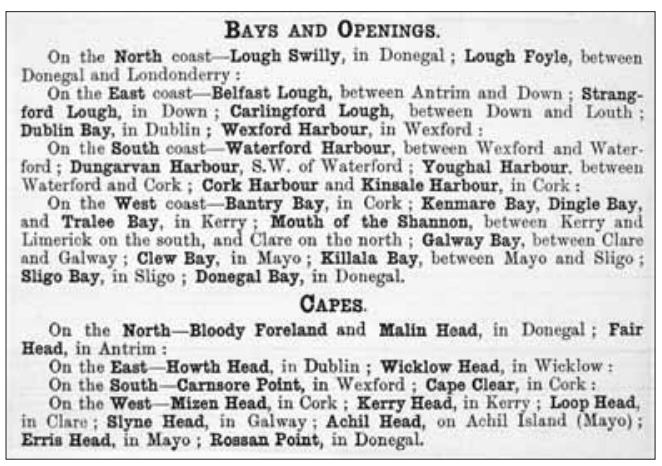

Figure 27. Detail of a page from Gill's Oxford \& Cambridge Geography (London, 1902), showing the use of bold (Clarendon) types. Approximately $70 \times 100 \mathrm{~mm}$.

25. The photograph, showing Nelson's Column with St. Martin-in-the-Fields in the background, was taken in the summer of 1844 (reproduced by Felix Barker and Peter Jackson in London: 2,000 Years of a City and its People [New York: Macmillan Publishing Co. Inc., 1974], 274, from an original in the Harold White Collection). 
design of the second half of the nineteenth century, particularly in geography and history textbooks (figure 27). But just how foreign such an approach was to book design in general can be gauged from the book Typography Now (London: BoothClibborn Editions, 1996), which proclaimed a similar new approach to the design of text (originating in the United States), that found favor for a few years only. Without the evidence we have from ephemera, the origins of this alternative form of reading-which now extends to electronic communication on the Web-would surely not be understood.

Ephemera also introduced the notion of what might be called "dialogue in typography," or perhaps it should be called "interactive typography." I am referring here to the humble form that we so hate to fill in, or the "blank form," as it was originally called (or even just "blank" in nineteenth-century America). Forms require the involvement of at least two parties, and completed forms consist of a standard element that elicits information, and a variable element provided by one or more other parties, usually by hand. The earliest example I can lay my hands on is a Dutch receipt of 1692 concerning a delivery of wine to Rotterdam (figure 28 ), though there are numerous earlier examples, difficult though they may be to locate.

In some eighteenth-century forms, both the predetermined part and the variable response to it were handwritten; surprisingly perhaps, this practice continued into the nineteenth century. But sometime in the mid-eighteenth century, in both Britain and France and presumably some other countries too, the printed form became

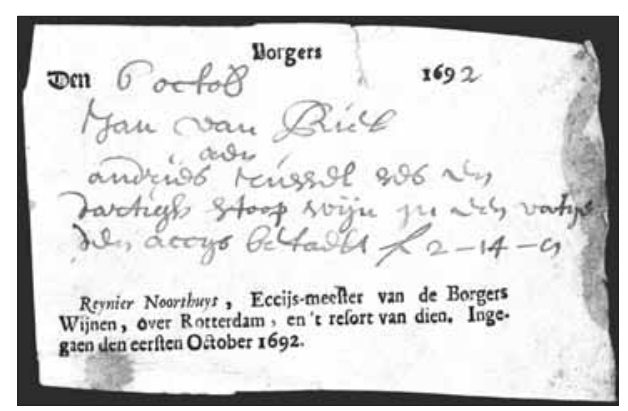

Figure 28. Letterpress-printed form concerning the delivery of wine, completed in manuscript, 6 October 1692. Printed in the Netherlands. $70 \times 100 \mathrm{~mm}$. widespread, forming part of a more general growth in bureaucracy and often associated with taxation. A catalogue of blank forms dated 1780 (figure 29), which was issued by J. Tymbs, the printer of the Worcester Journal, gives some idea of how widespread the form was by this time in Britain. Tymbs listed by name eighty-five different forms he could supply, and also referred to others in general terms.

Forms of this period usually aped the book by setting the copy in the manner of a page of text, but leaving gaps for the user to fill in (figure 30), the structure of the language indicating the kind of response needed. Some forms even followed the convention of chapter openings in books by introducing a heading and a large 


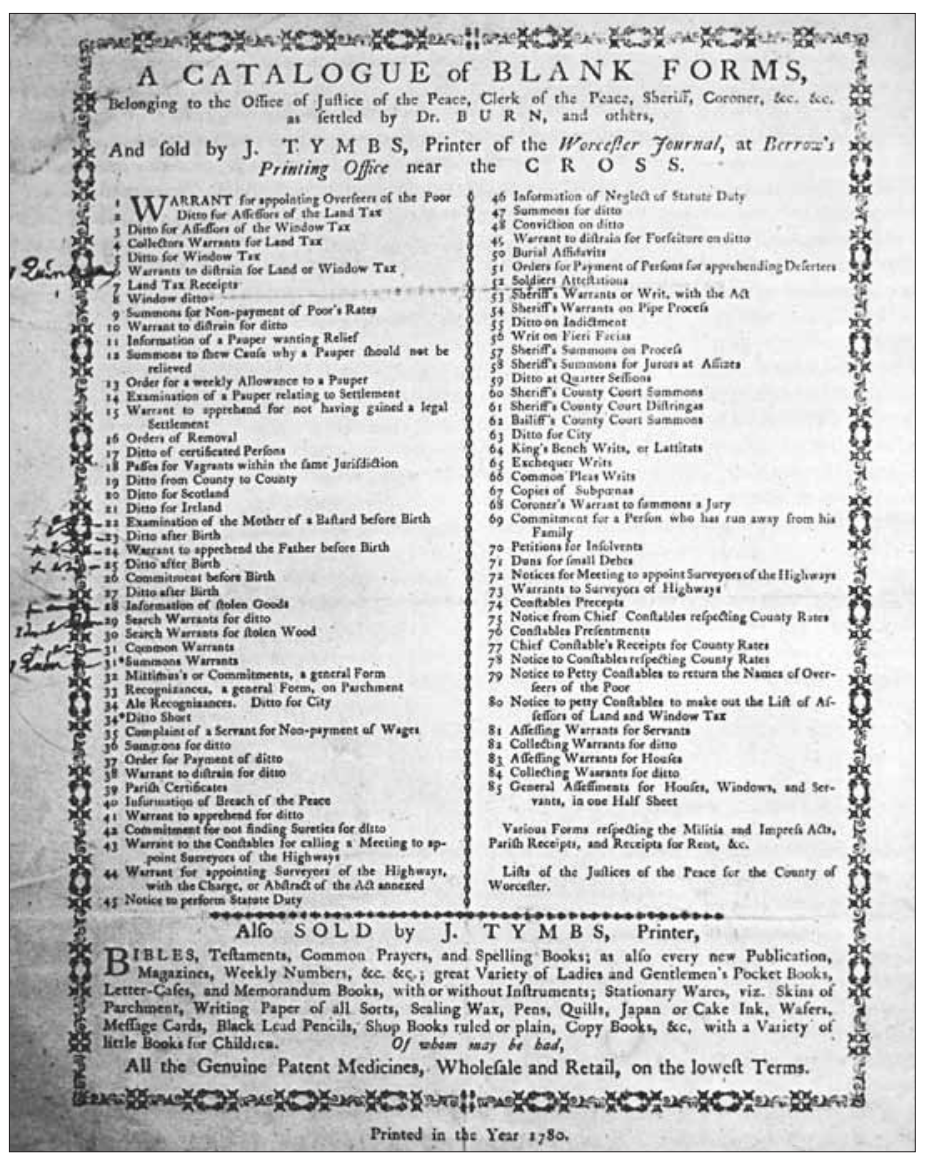

Figure 29. A catalogue of blank forms sold by J. Tymbs, printer, Worcester (UK), 1780. Letterpress. $412 \times 331 \mathrm{~mm}$.

initial letter at the beginning of the text. But, gradually, forms developed their own linguistic and graphic identity as a result of trying to make it easier for those who filled them in, and also, needless to say, the administrators who had to process the data. The consequence is that we can often identify the genre, without necessarily being able to read the language.

This French form of the early nineteenth century (figure 31) shows the use of rules, leader dots, and other typographic features commonly found on forms, which help characterize the genre. It was produced at a time when forms design in France was far more advanced than anywhere else. By the middle of the century, many British forms, particular ones relating to taxes, also had a clear graphic structure defined by rules (figure 32).

A century later, the scale of forms production had become enormous, and I provide some figures simply to emphasize the extraordinary impact forms have had on 


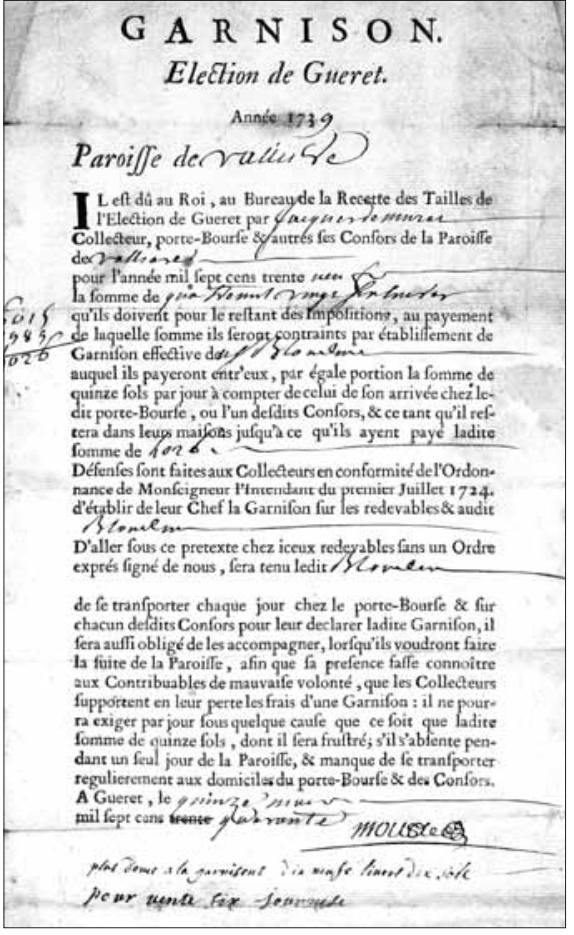

Figure 30. Letterpress-printed French form, completed in manuscript 15 March 1840. 300 x $180 \mathrm{~mm}$.

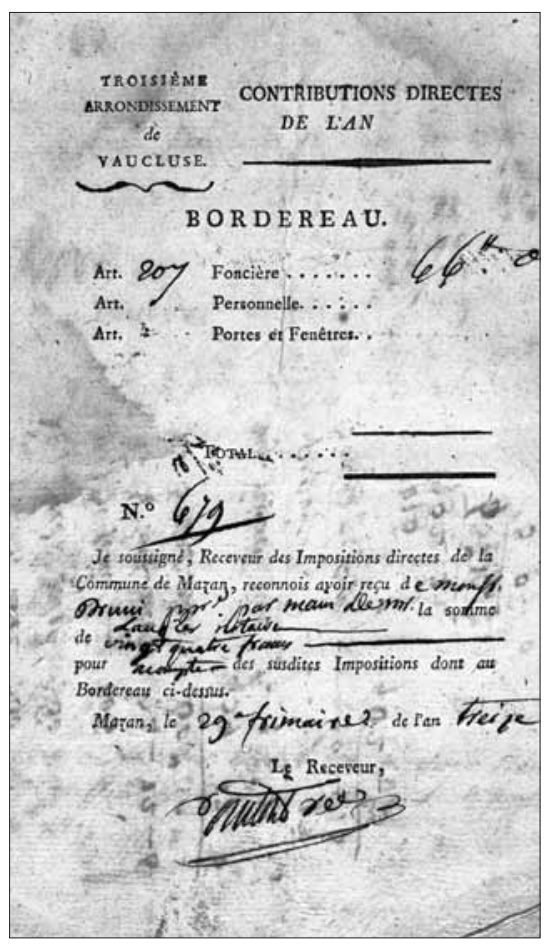

Figure 31. Letterpress-printed French form in a structured format, completed in manuscript “29 frimaire l'an treize," 1804. 215 x 130 mm
Figure 32. British Inland Revenue printed form relating to the year 1854, its structure defined by printers' rules. 265 x 208 mm.

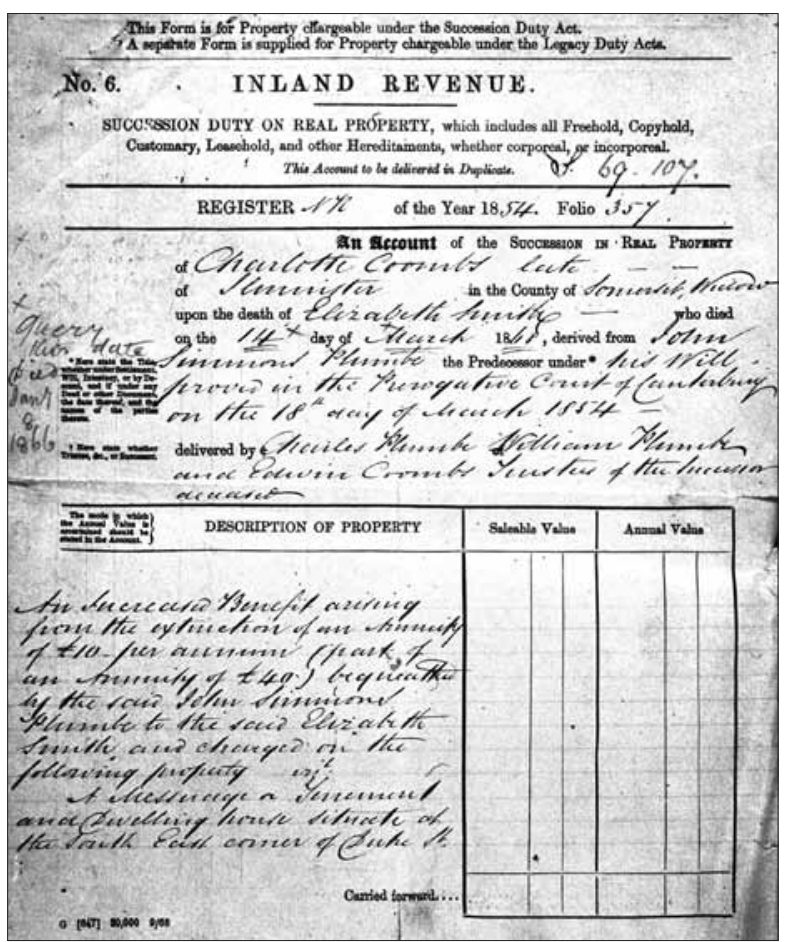


society. For example, in 1980 the British Inland Revenue estimated that it had 8,000 different kinds of forms, some produced in several millions of copies. Relatively, however, it was a modest player in the field. At that time the British Department of Health and Social Security estimated that it had something like 14,000 different forms, so many in fact that it did not know how many it did have. ${ }^{26}$ The form introduced yet another kind of reading, one that was designed to lead the recipient to respond systematically to what was written or printed. It could be argued that it marks the beginnings of interactive graphic communication-a bit slow perhapsbut still a kind of dialogue.

Just how pervasive and influential this category of ephemera has been can be deduced from certain expressions in the English language. One of these is the directive: write in "BLOCK capitals," a term with, as far as I am aware, no paleographic or typographic pedigree, but which simply means that letters should be written clearly and separately in legible characters. And where did the commonly used expression, "it ticks [or checks] all the right boxes" come from, if not from forms. Long ago another forms-related expression "sign on the dotted line," passed into everyday language in the English-speaking world. Forms of the late nineteenth and early twentieth centuries often did indeed require those who filled them in to sign on or above a dotted line, a practice that had been introduced by printers to control their responses. Now, however, the expression is used in everyday language to mean (according to the Oxford English Dictionary) that one fully accepts the terms offered. A couple of years ago I was amused to see on a television news program a report about the signing of the latest European Union agreement in Rome, and the commentator told us in measured tones that Tony Blair was now "going to sign on the dotted line." Well, he did not, at least not literally: along with other European leaders he signed on a page of a book without anything as demeaning as a dotted line in sight.

This subject leads naturally to the question of the language of ephemera in general, and also to its pointing or punctuation. I have drawn attention to a few examples in passing, but the subject warrants further comment. Except perhaps in advertising, the study of the language of ephemera is a neglected field, but it offers interesting possibilities for study in other areas too. ${ }^{27}$ Shifts in orthography can certainly be charted in some fields of ephemera with a degree of precision. A French receipt of 1734 (figure 33) shows the old-style spelling of "il a esté taxé" and "mil sept cens trente-"; whereas its successor, which was printed, or at any rate filled in, the year afterwards, has the new style spelling of these words: "il a été taxé" and "mil sept

\footnotetext{
26. "Forms Reform. Second Progress Report to the Prime Minister by the Cabinet Office (Management and Personnel Office)," April 1984, Appendix C.

27. See, for example, the pioneering work of D. Crystal and D. Davy, Investigating English Style (London: Longman, 1969).
} 


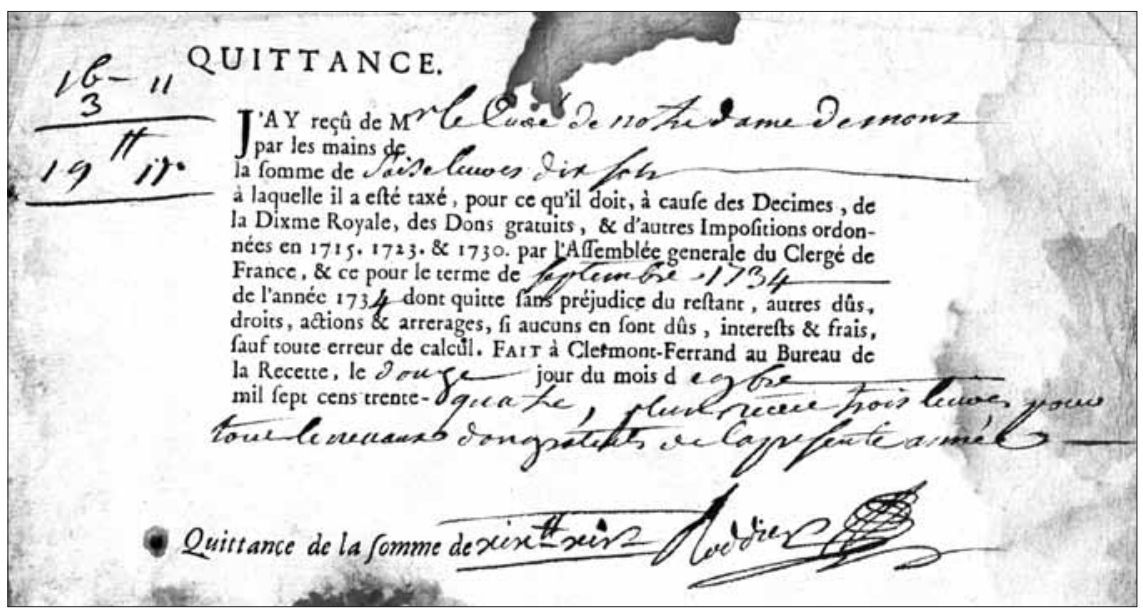

Figure 33. French letterpress-printed receipt, completed in manuscript 12 February 1834. 190 x $230 \mathrm{~mm}$.

cent trente-" (figure 34). What makes this comparison all the more significant is that there is clear evidence that the type had been kept standing, which means that these linguistic changes must have been very deliberate ones.

It seems likely, therefore, that for centuries some new words and expressions ("sign on the dotted line" among them) found their way into the public domain first of all in ephemera, and this has been demonstrated recently by the team of scholars working on the Oxford English Dictionary, with the help of the British public (the example that springs to mind is "ploughman's lunch" - which is first recorded on

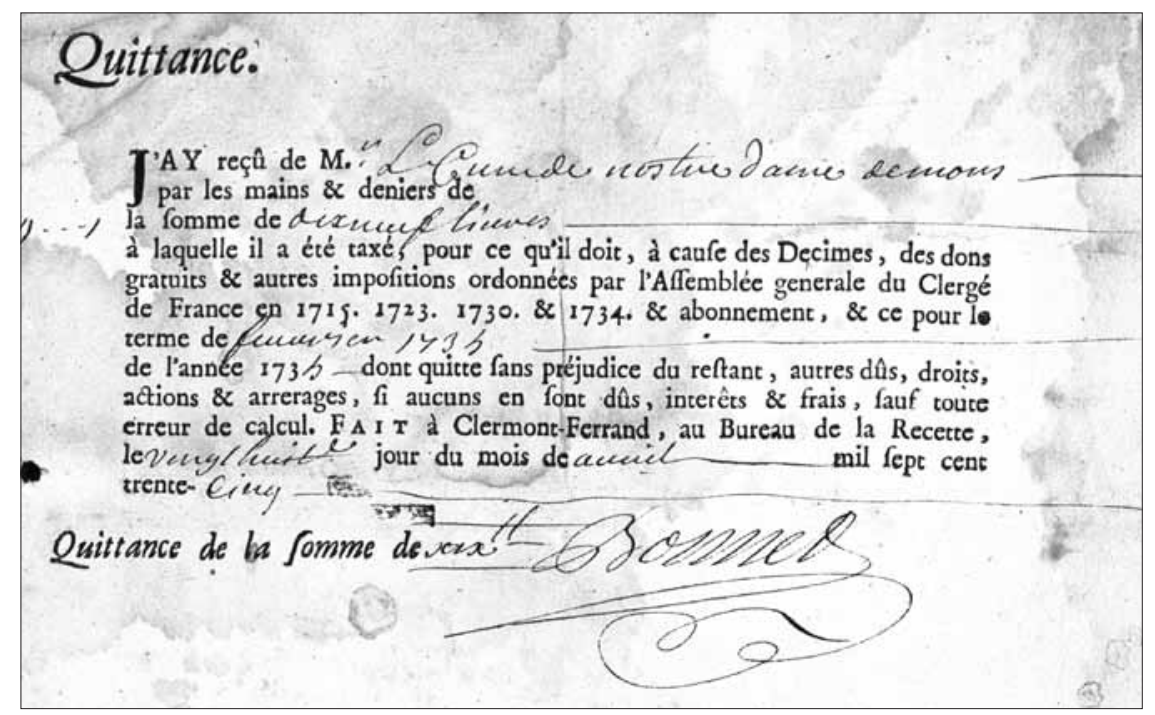

Figure 34. French letterpress-printed receipt, showing newer forms of orthography for some words compared with the 1834 version (figure 33). Completed in manuscript 28 April 1835. $180 \times 235 \mathrm{~mm}$. 
an advertisement of the Cheese Council). Paradoxically, however, early ephemera tend to be formulaic in their language, and we find certain expressions continuing to be used for many decades. Some of the most persistent appear in the form of opening lines to notices, such as: "To the inhabitants/voters of," as seen on electoral broadsides; "Whereas by some evil-disposed person or persons," on reward notices; and "To cover this season," on stud notices (figure 35).

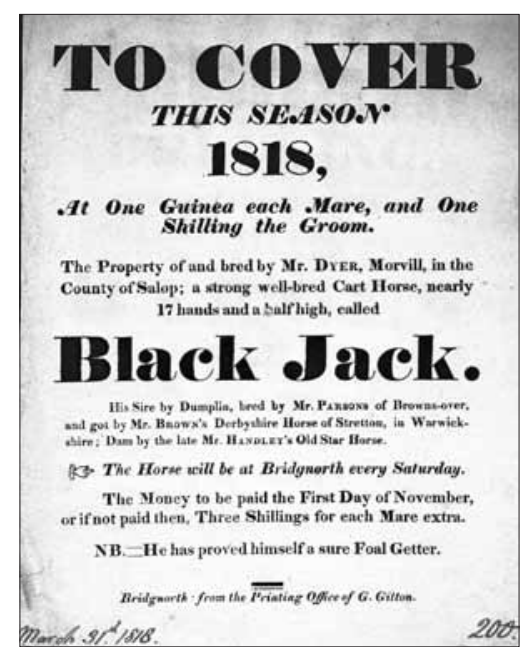

Figure 35. Stud notice, 1818. Letterpress. Printed by G. Gitton in Bridgnorth, with the initial lines of copy conventionally associated with the genre. $240 \times 187 \mathrm{~mm}$.

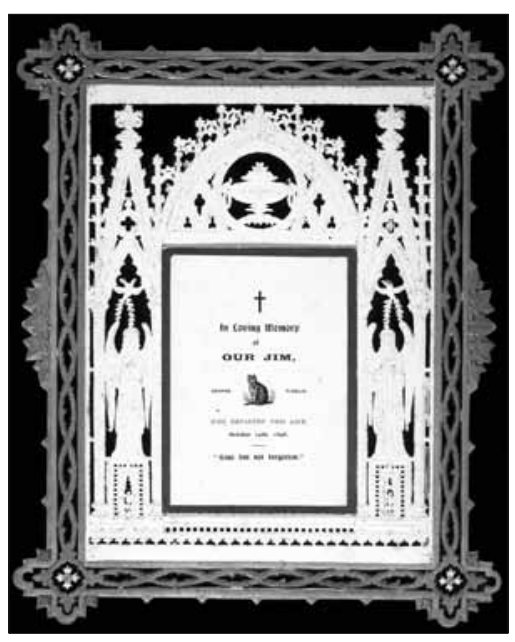

Figure 36. In memoriam card for a cat, with the wording "In loving memory of our Jim, semper fidelis, who departed this life October 14th 1898. 'Gone but not forgotten'." Printed in pink, green and black, and then embossed and die-cut.
Ephemera are also of interest linguistically for the subsets or registers of language they reveal. It hardly takes an expert to recognize the legalistic nature of the language of many forms, which often included words that no longer have general currency. For example, the term "hackney carriage," which originally meant a horse-drawn carriage, continued to be used on British vehicle licence forms for petrol- or diesel-driven cars because it had a specific legal meaning: "a vehicle publicly plying for hire." Language of this kind is not difficult to distinguish from the hyperbole of advertising, which often relies on imprecision and humor, and can never afford to appear old fashioned. These two subsets of language are obvious enough, but others are more particular, such as the language of mourning, illustrated on an "in memoriam" card for an animal, with its Latin expression "semper fidelis" (figure 36); or, looking on the brighter side, the language of entertainment, as seen in a poster for Chinese magicians with its liberal use of exclamation marks (figure 37). All such features tell us something about society in the past and the very particular ways it had of responding to different situations.

Ephemera also offer opportunities for study that parallel historical bibliography. My examples, taken from the field of popular sheet music, are four very similarly illustrated covers for the highly popular Scottish 


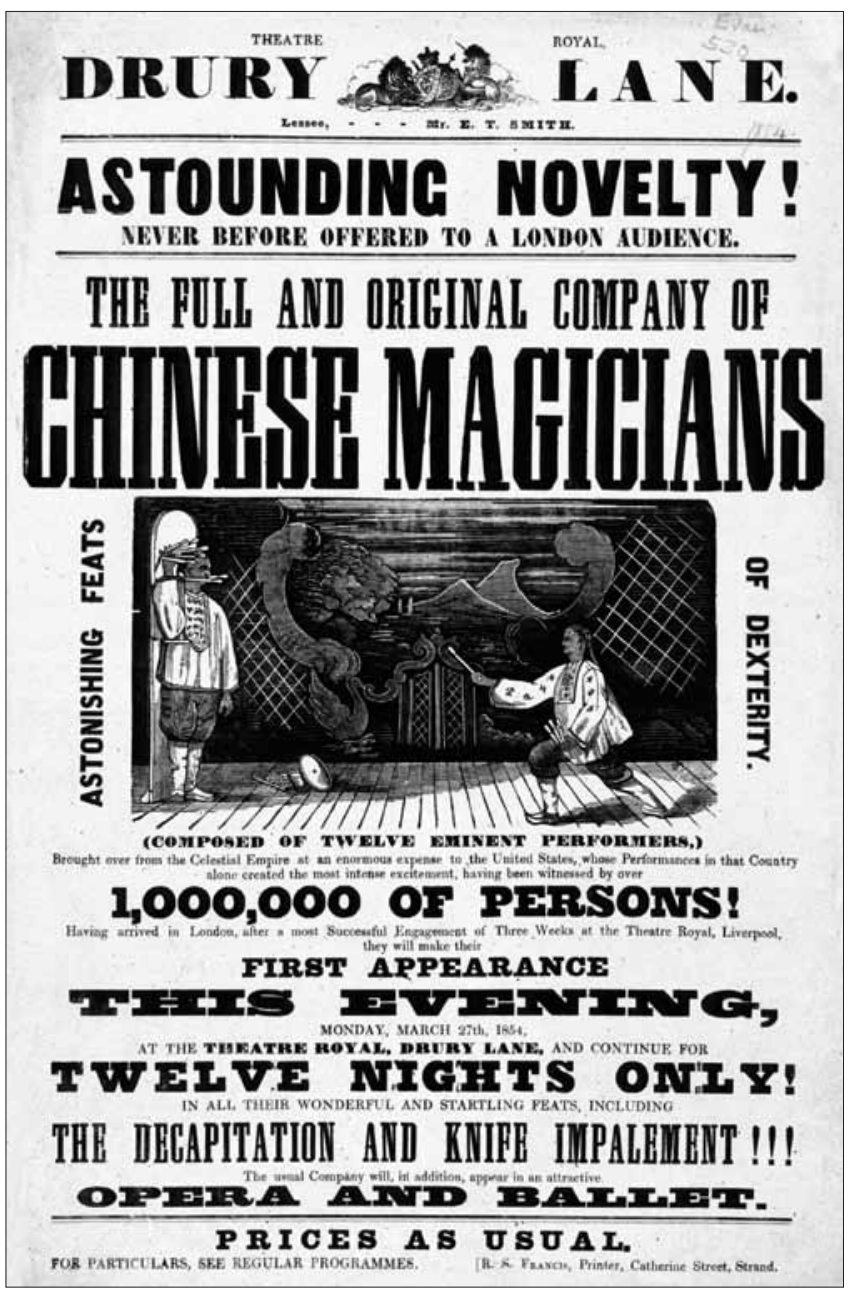

Figure 37. Theater bill for the Theatre Royal Drury Lane, London, 1854, showing extravagant language and a liberal use of exclamation marks. Letterpress, with woodcut. Printed by R. S. Francis, London.

song, "Annie Lawrie" (figures 38-41), one of which is assumed to be an early work of Winslow Homer. All four were published in Boston by Oliver Ditson in the 1850s: the problem is how to establish a definitive date order for them on the basis of the imagery, imprint information, and other criteria.

We also have the question of plagiarism, which was rife in popular sheet-music publishing. Figure 42 shows a London edition of "Chimes of Zurich," published by Mayhew ca. 1830; and figure 43, a remarkably similar version published in New York by Hewitt, fortuitously perhaps, described as the second edition. Well-known paintings suffered the same fate. It was surely the Millais painting "Yes or No" of 1871 (now in Yale Center for British Art) that provided the source for an almost identical image on a Ditson sheet-music cover. And a woodcut on a broadside for 
a British maritime disaster printed by Catnach, the well-known London printer of street literature (figure 44), was simply lifted from Géricault's painting the "Raft of the Medusa" of 1819, which was exhibited in London from 1820 to 1822 and is illustrated here on a piece of late nineteenth-century ephemera, one of a series of miniature chromolithographed reproductions of paintings in the Louvre used as advertising by Biscuits Olibert (figure 45).

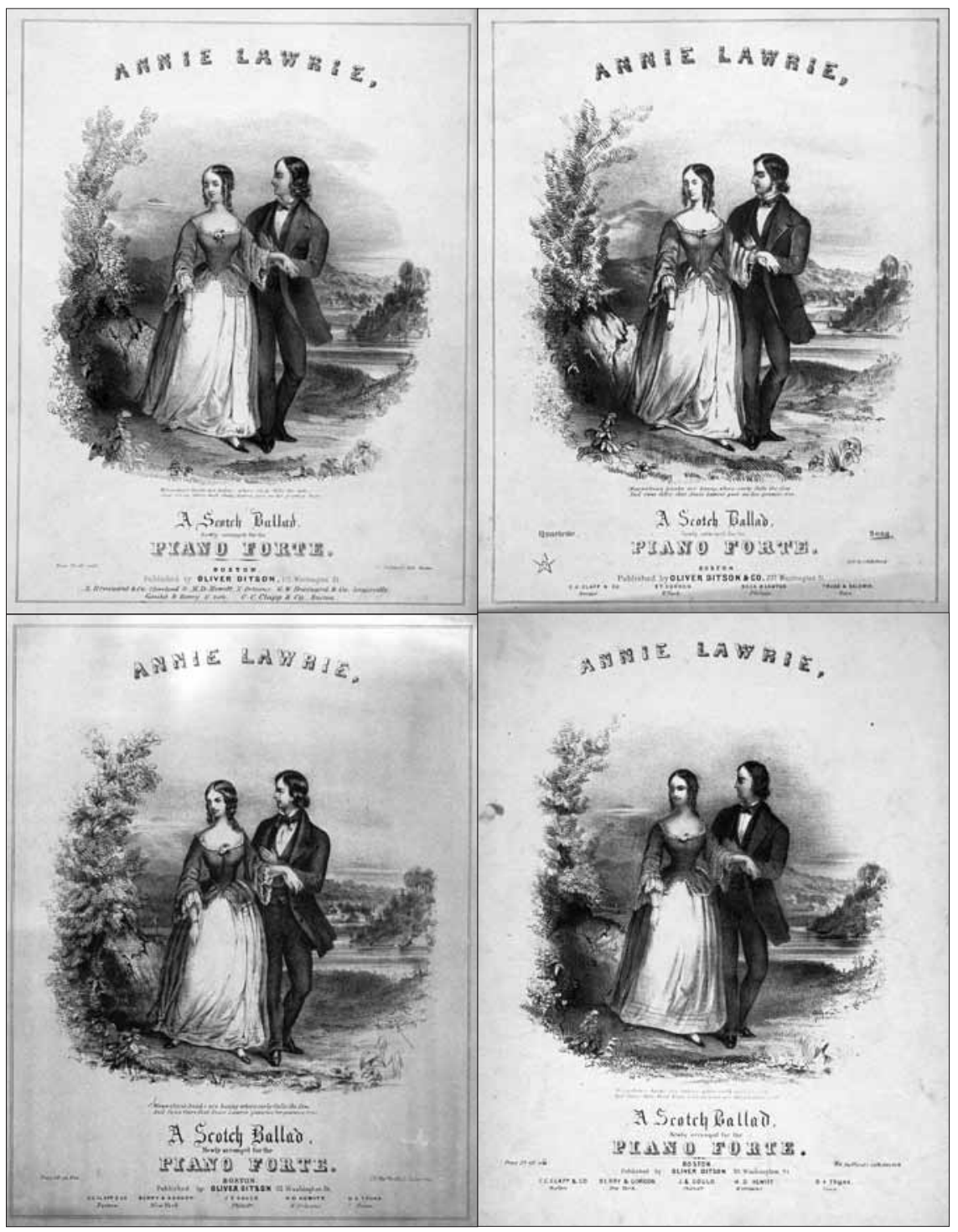

Figures 38-41. Four versions of the cover of "Annie Lawrie, a Scotch ballad newly arranged for the piano forte," all printed lithographically by J. H. Bufford in Boston and published there by Oliver Ditson in the 1850s. The variations in the images and imprint statements of these covers present fascinating challenges to those interested in determining the sequence of the issues. 
The truth is that we are only at the very beginning of taking ephemera seriously from all the points of view I have briefly outlined: and that should be as much a cause for excitement as it is for regret, especially for $\mathrm{PhD}$ students and others searching for topics to investigate.
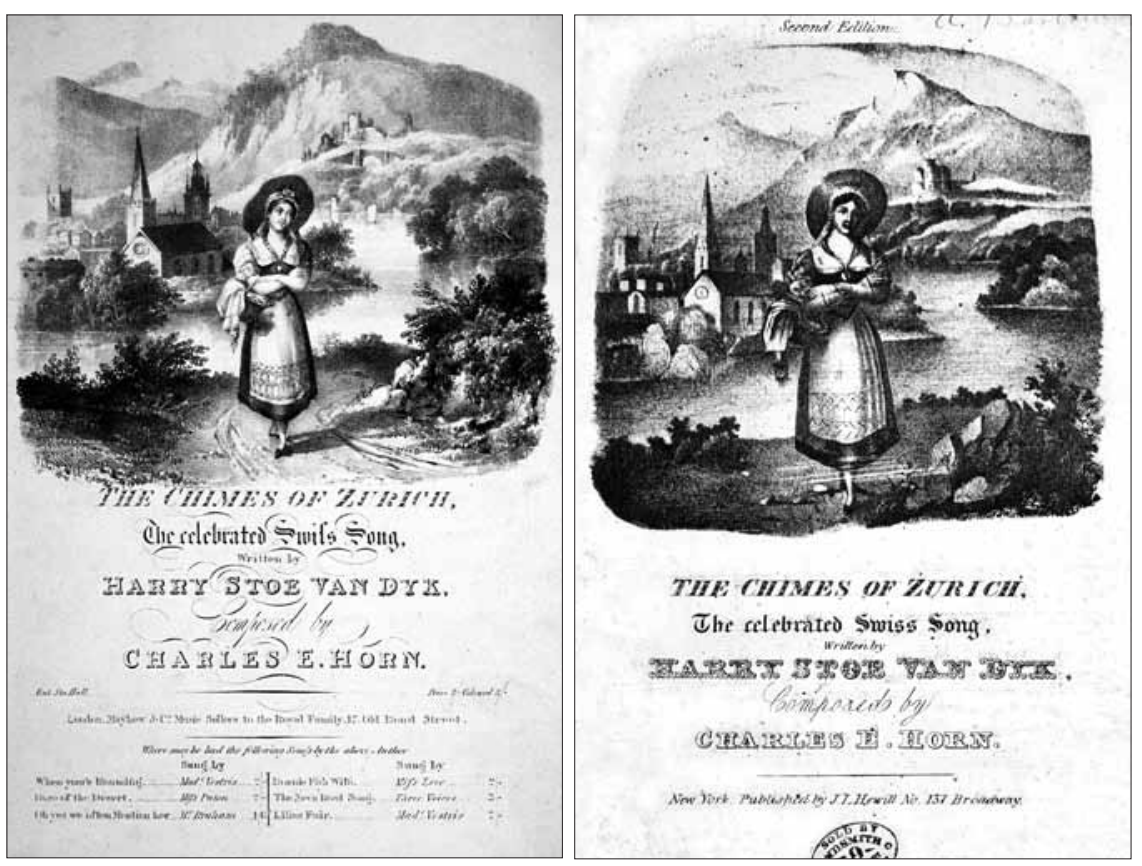

Figures 42-43. Two editions of "The chimes of Zurich," written by Harry Stoe Van Dyk and composed by Charles E. Horn. Figure 42, with a lithographed vignette and intaglio-printed words, published in London by Mayhew \& Co.; figure 43, with the vignette and words lithographed, published in New York by J. L. Hewitt as a "second edition."

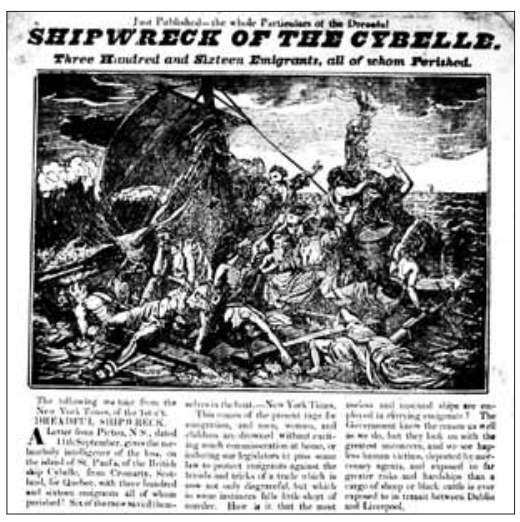

Figure 44. Top half of a broadside "Shipwreck of the Cybelle." Letterpress with woodcut, printed by J. Catnach, London. The image based on Géricault's painting "Le Radeau de la Méduse." Whole sheet 380 × 260 mm.

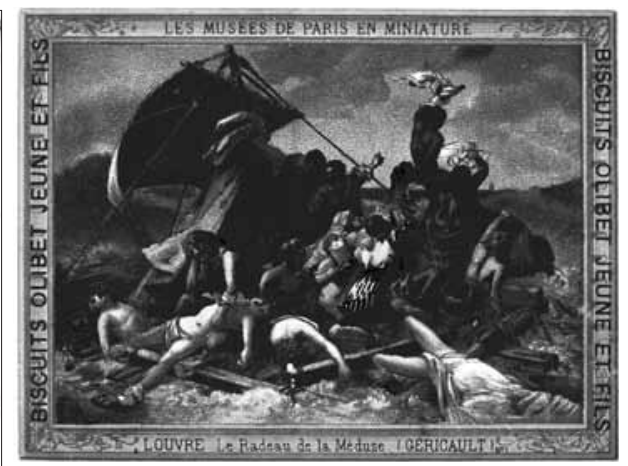

Figure 45. Reproduction of Géricault's "Le Radeau de la Méduse," in the series "Les Musées de Paris en miniature" and overprinted as an advertising card for Biscuits Olibert jeune et fils. Chromolithographed. Late nineteenth century. 
At the beginning of this article, I presented some comparative figures to support the argument that book printing accounted for only a small proportion of the total output of the British printing industry, as judged both by value and by the number of workers employed in it. In the last part of this paper I would like to expand a little on this issue without getting too specialized. The figures provided by Alford for 1831 and 1851, which I cited earlier, relate to three categories: book printing, government printing, and jobbing. This division reflected what was possible in terms of data collection, rather than the sectors of the industry as they would probably have been recognized at the time, or as we might define them today.

Throughout most of the nineteenth and twentieth centuries, several more or less clearly defined industry sectors can be identified within the printing and related trades, among them book and periodical printing, newspaper and magazine printing, security printing, packaging, stationery, and jobbing printing. Some of these broad categories could be broken down even more precisely to reveal specialists in, for example, academic books, picture printing, fancy printing, tin-plate printing, and the printing of music, maps, playing cards, paper bags, labels, railway tickets, ${ }^{28}$ and to even more precisely defined fields, such as the black bordering of mourning stationery and, in Britain, cricket scorecards, which were printed on the ground in the case of the most important clubs.

But however the printing cake is divided, it reveals numerous categories in which ephemera figure very strongly indeed. And the more precisely the printing and allied trades are studied, the more it becomes evident that many technical innovations were made with newspapers and ephemera in mind rather than books. In more or less every respect, book production lagged well behind other areas of printing in its response to technical, social, and design innovations.

Some very obvious examples of such innovations in ephemera spring to mind. Around 1820, and coincidentally just in time for the particularly lavish Coronation of George IV in 1821, a security printing process was invented called compoundplate printing (figure 46). ${ }^{29}$ It was one of the many attempts to circumvent the forgery of banknotes. In essence, the process involved making a printing plate in two parts, which could be engraved as though they were one piece, divided so that they could be inked in different colors, and then brought together for printing at one

28. Categories of this kind are to be found among the headwords of London trade directories from around the middle of the nineteenth century onwards.

29. The process has attracted considerable attention. See, in particular, M. Greenland and R.E. Day, Compound-Plate Printing (London: Foundation for Ephemera Studies, 1991), and two works by E. Harris, Sir William Congreve and his Compound-Plate Printing (Washington: Smithsonian Institution Press, Bulletin 252, 1967), and "Experimental Graphic Processes in England 1800-1859, Part 1," Journal of the Printing Historical Society, 4 (1968): 34-86. 
pass through the press. The process was used for a range of semi-security printing, such as medicine tax labels, and labels to secure packaging, but also for lottery bills and even-Dickens scholars should note-blacking labels (figure 47), partly, and perversely, because of its association with prestige items of printing. As far as we know, compound-plate printing had no application outside what we would describe as printed ephemera.

The same would probably be true of die-stamping and embossing. Diestamping, which produces a raised and printed surface (figure 48), was commonly applied to monograms, coats of arms and other devices on stationery, and also on greeting cards. Embossing, either blind or with a printed background, is mostly found on the borders of greeting cards and stylish invitations, such as this one for the Yorkshire Music Festival in 1838 (figure 49). It was also used for borders on stationery, particularly in France, where children in schools were encouraged, one could say coerced, to write home to their parents to say how much they were enjoying and benefiting from their education. Additionally, embossing provided a means of putting preprinted pictures into slight relief, as in chromolithographed scraps or die-cuts of one sort or another and,

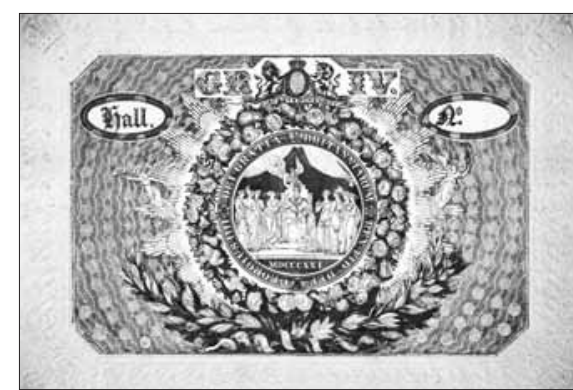

Figure 46. Admission ticket for the coronation ceremony of George IV in Westminster Hall in 1821. Printed in three colors by Whiting \& Branston using the compound-plate process, with an embossed border by Dobbs. Image with embossed border. $175 \times 248 \mathrm{~mm}$.

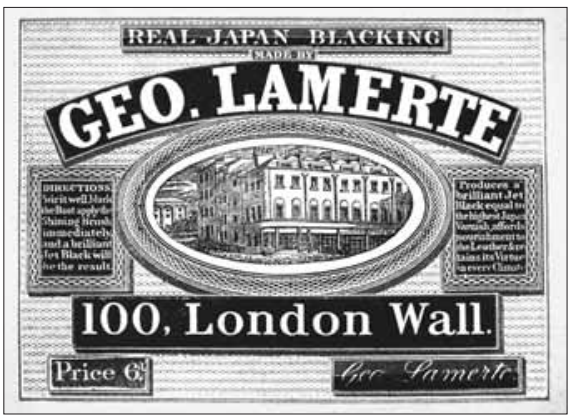

Figure 47. Blacking label for George Lamerte. Printed by the compound-plate process in red and black.

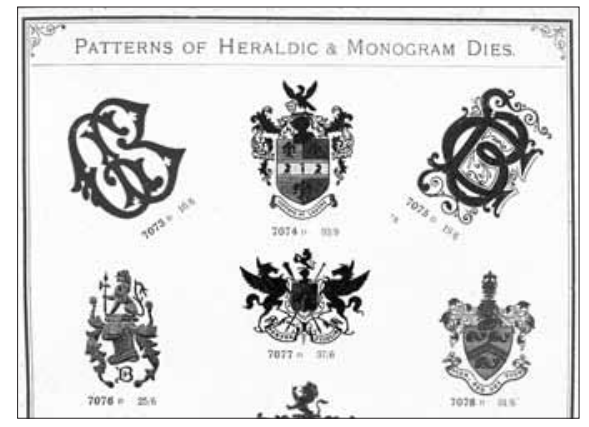

Figure 48. Detail of heraldic and monogram dies, from [Baddeley Brothers], Specimens of Dies, Seals, Visiting Card Plates, \&c. \&c. [London, ca. 1900]. $90 \times 135 \mathrm{~mm}$.

particularly in France, advertising calendars and "vides poches." But for obvious practical reasons, processes that created a raised surface are not normally found in books, which are submitted to a pressing process as part of their normal manufacture. Compound-plate printing and various kinds of stamping and embossing found very few applications outside ephemera. And if our concern were solely 


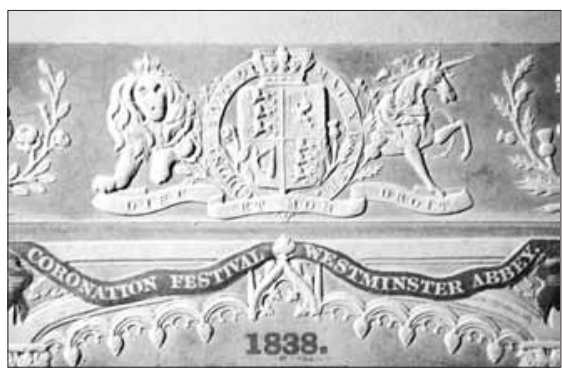

Figure 49. Detail of a ticket for a grand performance of sacred music in Westminster Abbey, 1838. Printed in two colors and embossed by Whiting Jnr, London. Approximately 57 x 85 mm.

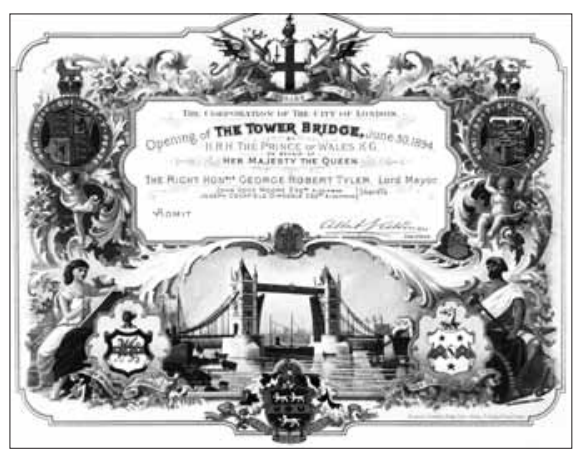

Figure 50. Ticket for the opening of the Tower Bridge by the Prince of Wales, 1894. Designed and chromolithographed in ten colors with additional printing in gold and silver, hand-coloring, and embossing. $260 \times 320 \mathrm{~mm}$.

uct display cards, and prestigious invitations, such as one for the opening of Tower Bridge in 1894 (figure 50).

Statistically, lithography's contribution to the history of the book-apart, that is, from the provision of illustrations and covers-was minimal until the second half of the twentieth century, and it had virtually no application at all in newspaper production until the same period. A rare and notable exception was a special George IV coronation issue of 19 July 1821, in which a single illustration was printed lithographically on the letterpress-printed sheets of text. Lithography owed its considerable commercial success almost entirely to ephemera and some specialties of the trade, among them transfer lithography, a process that was called engraving on stone, and even chromolithography came to be associated with particular categories of work. So closely was chromolithography linked with ephemera that the word "chromo" is still loosely used in both French and Spanish to describe all kinds

30. M. Twyman, Breaking the Mould: the First Hundred Years of Lithography, the Panizzi Lectures for 2000 (London: The British Library, 2001). 


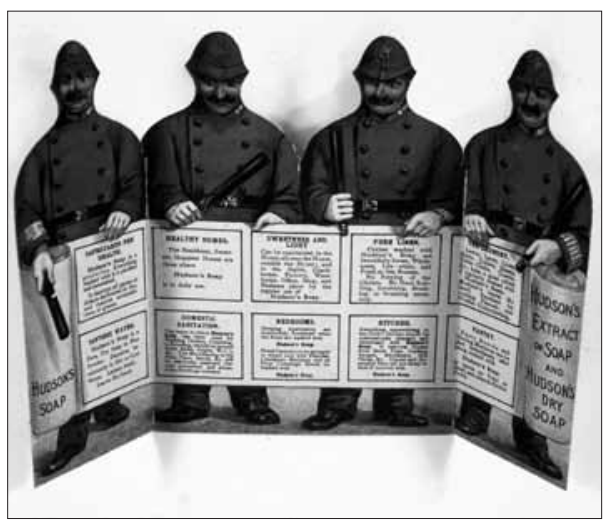

Figure 51. Hudson soap advertisement of the 1880s. Chromolithograph, signed JBB. $153 \mathrm{x}$ $226 \mathrm{~mm}$.

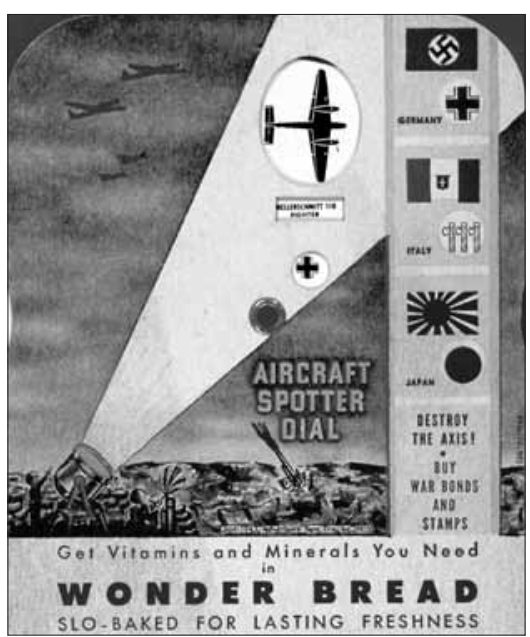

Figure 52. Moveable aircraft spotter dial advertising Wonder Bread, Advertisers' Serv. Dir. Inc., New York, 1943. Photolithography in three colors. $131 \times 112 \mathrm{~mm}$.

of small items of ephemeral color printing (regardless of how they were printed). And curiously, one of the definitions for "Chromo" in the 1934 edition of Webster's dictionary extended its meaning beyond printing to "anything cheap and ugly."

Many other techniques in printing were developed specifically with ephemera in mind, or can be identified closely with them. Among them are die-cutting and the techniques of folding and perforating paper and card to produce shaped objects, such as advertising novelties, scraps, envelopes, and packaging. There are folded and shaped pieces of ephemera that stand up, among them a two-sided advertisement for Hudson's soap (figure 51), inspired, one assumes, by Gilbert \& Sullivan's Pirates of Penzance, which was all the rage in the 1890s; and others that create smallscale stage sets or peep shows. There are also items with movable parts that involve the participation of the user, as does an air-spotting device from World War II (figure 52), or a delightful multilingual flower arranging kit, the components being a sheet with slits in it (figure 53) and a set of paper flowers (figure 54), from which one could produce whatever was wanted (figure 55). Of course, there are books with movable parts, including pop-up books, and there are even shaped books, but both are very much the exception.

If we extend the same argument to the substrates on which printing was done, again it was ephemera that provided the lead. How often were books, or even newspapers, printed on colored paper, let alone rainbow-colored paper? I can think of one extraordinary French book of the 1820s, which in some copies was printed on a variety of colored papers, each section or quire on a differ- 

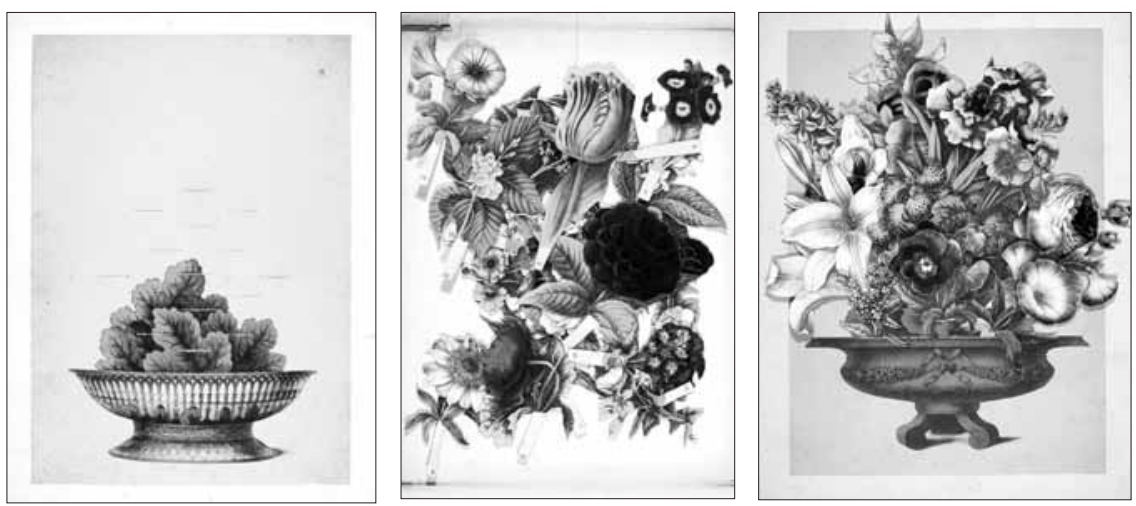

Figures 53-55. Components of a flower arrangement pastime, mid nineteenth century. Lithographed and colored by hand.

ent color. ${ }^{31}$ In Britain, the Financial Times and some sporting newspapers have made a point of using color to single themselves out from other publications, and the success of what we know as "yellow pages"-pioneered in America and copied throughout the world-is predicated on its departure from the norm. ${ }^{32}$ Understandably, books printed on colored paper are a rarity; but just as rare are books printed on coated card, silk, cellophane, celluloid, wood, and tin. Yet these substrates were not at all unusual in printed ephemera: tin, for example, became more or less standard for certain kinds of packaging, such as sardine cans and presentation biscuit tins, including examples produced in my home town of Reading for Huntley \& Palmers in the 1890s (figure 56). ${ }^{33}$ In short, it is to ephemera that one has to go to see the full range of printing processes and materials that were in commercial use from the late eighteenth century. If we had nothing but books and newspapers to go by, we would form an extremely narrow view of the technologies used by the printing and allied trades.

Such matters may be of central interest solely to printing historians, but one other feature of ephemera that seems to have left its mark on printed matter in recent decades has had much wider ramifications. I am referring to the integration of text and picture. If we were to engage in the broadest possible sweep of the history of graphic communication in Western Europe, we would see words and pictures

31. The work in question was a large-paper copy of A.C. Ducarel, Antiquités anglo-normandes, traduites de l'Anglais par A. L. Léchaudé d'Anisy (Caen: Mancel, 1823-25). It may have been one of the copies advertised on the rear wrappers of the octavo edition as "tiré à petit nombre," which sold for 12 fr compared with 5 fr or 7.5 fr for other copies.

32. According to P. Robertson, The New Shell Book of Firsts (London: Headline, 1995), 543, the first "yellow pages" were published in Chicago in 1886. The rarity of books printed on colored paper is underlined by an entry in a recent Marlborough Books catalogue (December 2004) where item 112, Alphonse Karr, Voyage autour de mon jardin, 2 vols, Paris, 1845, is emphatically described in all-capital letters as "Printed on green paper."

33. See H. M. Clark, The Tin Can Book (New York: New American Library, 1977); M. Ducamp, Boites en fer (Paris: Flammarion, 2002); M.J. Franklin, British Biscuit Tins 1868-1939 (London: New Cavendish Books, 1979). 
combined at certain periods, but not in others. In both the classical world and the Renaissance, texts usually had no illustrative elements; conversely, pictures in these periods included no more than the occasional word (a label of some sort, or a quotation). In the Middle Ages the situation was very different: pictures and words were often, if not usually, combined, not only in manuscripts and paintings, but even in sculpture, as in the cloisters of St.

Pierre in Moissac, or on the relief panels of the facade of S. Zeno in Verona.

With the invention of printing from movable type, the separation of words and pictures was reinforced, not only for technical and organizational reasons, but also because by this time the word had been invested with an authority that derived on the one hand from the legacy of the ancient world, and on the other from the Bible (the Word of God). Pictures, if not actually pernicious, were suspect and had to prove themselves. In the first few centuries of printing they appear in what might be described as informational or practical books-technical manuals, herbals, anatomy books, and, later, books of natural history and travel—but such books were by no means common until the nineteenth century. Even then, illustrated books rarely integrated text and pictures in any real sense (that is, with regard to both their content and the book's physical construction). In general, ephemera had no cultural baggage of a kind that favored text, and we find pictures and words combined almost

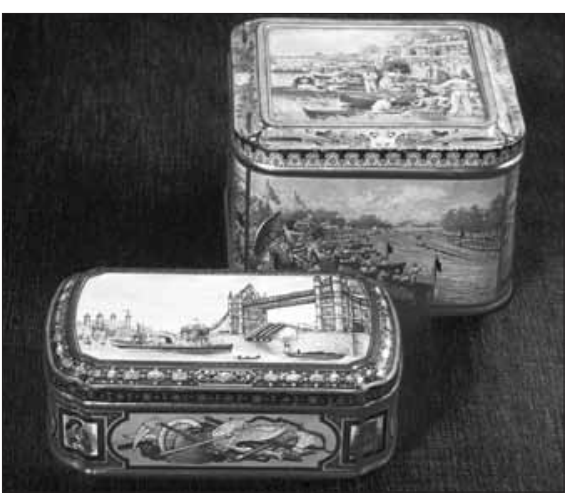

Figure 56. Huntley \& Palmers' biscuit tins, mid 1890s. Printed by means of offset lithography by Huntley, Boorne \& Stevens Ltd, Reading (UK).

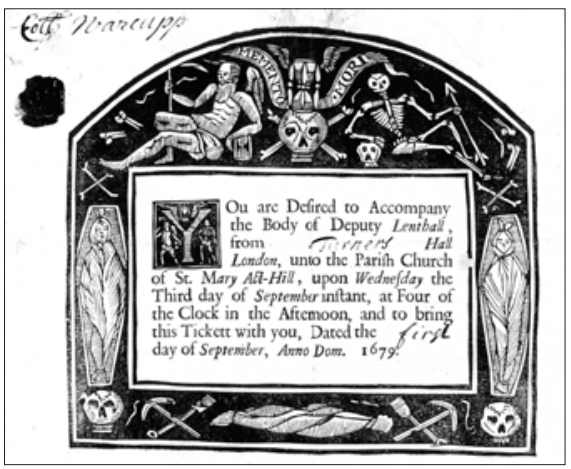

Figure 57. Funeral invitation, 1679. Letterpress with woodcut border and initial letter.

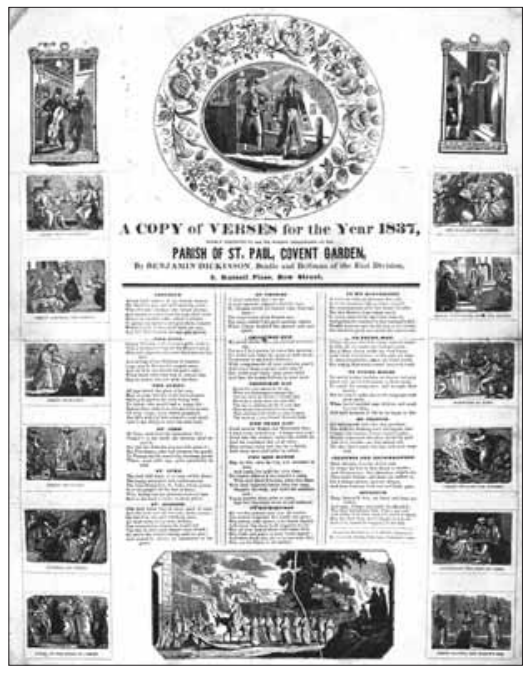

Figure 58. Bellman's verse. Letterpress with wood-engraved images. Printed and published, by J. V. Quick, London, 1837, for Benjamin Dickinson, beadle and bellman of the Parish of St Paul, Covent Garden. 534 x 442 mm. 


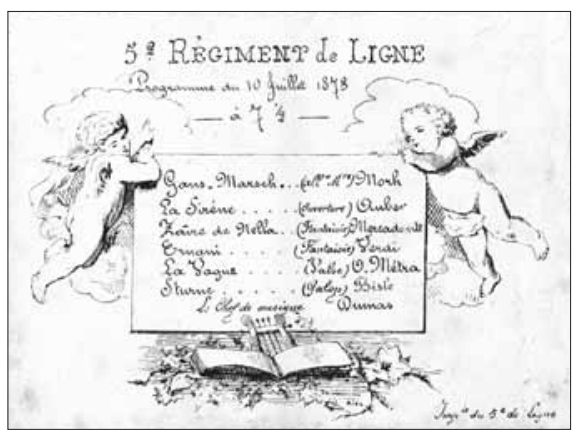

Figure 59. Program of music played by the $5 \mathrm{e}$ Régiment de Ligne, 10 July 1873. Written and drawn on transfer paper and printed on the regiment's lithographic press. 103 x 139 mm. from the beginning of certain categories of printed ephemera, among them funeral cards (figure 57), ballads, trade cards, popular prints (including religious ones), execution broadsides of the first half of the nineteenth century, and what were called "bellman's verses" (figure 58). The technical constraints that often kept pictures and text apart were genuinely restrictive. Crude pictures and text could be cut on wood together, as in block books of the fifteenth and early sixteenth centuries, or woodcuts could be printed alongside type (as in figures 57 and 58). But more refined images of the kind produced by etching or engraving on copper had to be printed separately from type. In effect, neither of these technologies met all the needs of those who may have wanted to integrate pictures and words.

All this changed with the invention of lithography at the close of the eighteenth century. ${ }^{34}$ For the first time there was a printing process that offered something like the facility to combine pictures and words that existed in the manuscript age (figure 59), and at costs much lower than those of copper engraving. If anything, this new technology favored pictures rather than words, though words presented no great problem. The process was also relatively cheap and could be used to print long runs when they were needed. For these reasons, it was eagerly taken up for printing all kinds of ephemera, first of all for monochrome work, and later on for color. The hotel card illustrated as figures 60 and 61 makes the point more elegantly: it was produced in the 1840s and explored the flexibility of the relationship between text and pictures, featuring on one side the front of the hotel, and on the other the view of Windsor Castle guests would get from it.
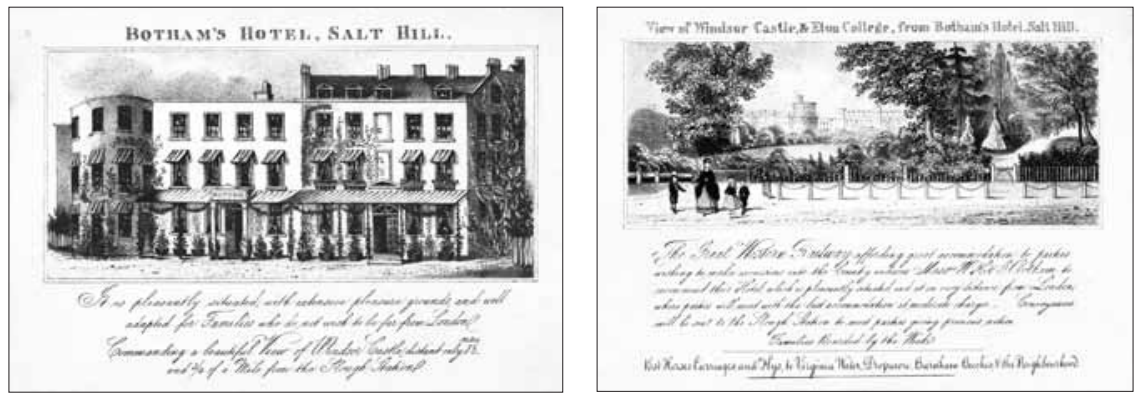

Figures 60-61. Advertising trade card of the 1840s for Botham's Hotel Windsor, shown back and front. Lithographed in crayon and ink and colored by hand. $145 \times 205$ mm.

34. For development of this argument, see Twyman, Breaking the Mould. 


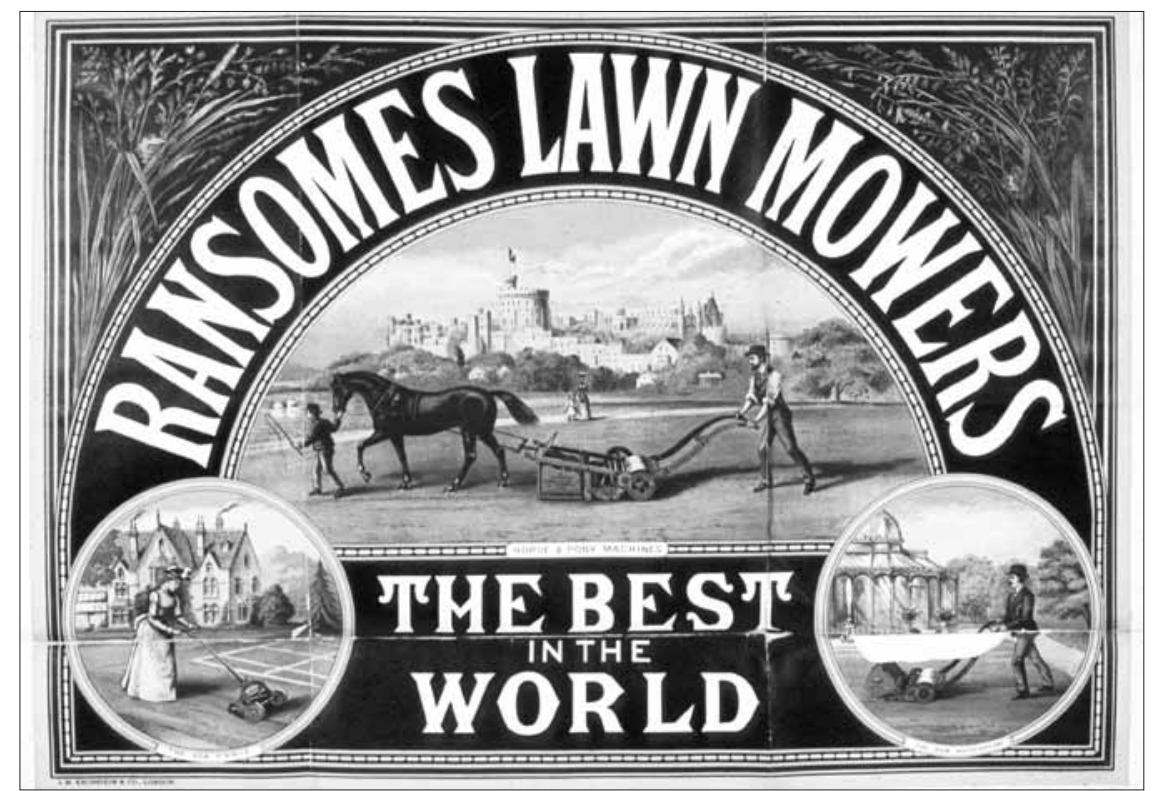

Figure 62. Poster for Ransomes lawn mowers. Chromolithographed by J. M. Kronheim \& Co., London, late nineteenth century.

Later in the century, with the development of chromolithography, the idea was extended to ephemera in full color for advertising and all sorts of other work, as in figure 62 where we see Windsor Castle featured again, though perhaps with less justification.

I am not claiming that ephemera were alone in taking advantage of the opportunities to combine pictures and words in this period, simply that they did so more fruitfully and also more integrally than was normally done in books and other categories of printing, where publishing traditionally started with a text. Sometimes, in ephemera, lithographed pictures and words were physically interlocked: words could be fully integrated into pictures as they are on a piece of chromolithographed publicity for the Strand Theatre in London (figure 63), or more subtly on a sheet-music cover of the late nineteenth century, in which the word "polka" floats across the waves (figure 64). Occasionally, letters and words were even drawn so as to become things and create their own pictorial reality (figure 65). How such ephemera affected the way people reacted to messages is impossible to say at this distance

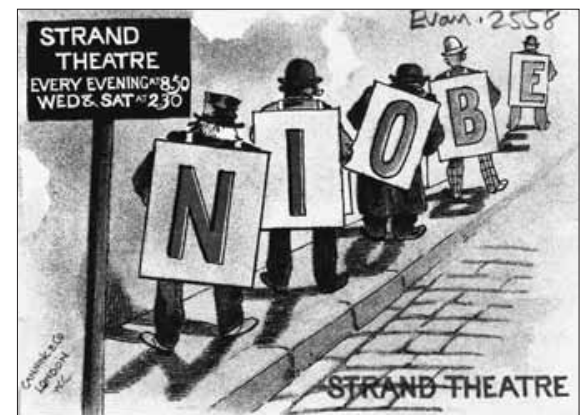

Figure 63. Advertisement for the Strand Theatre. Chromolithographed by Canning \& Co., London, late nineteenth century. 


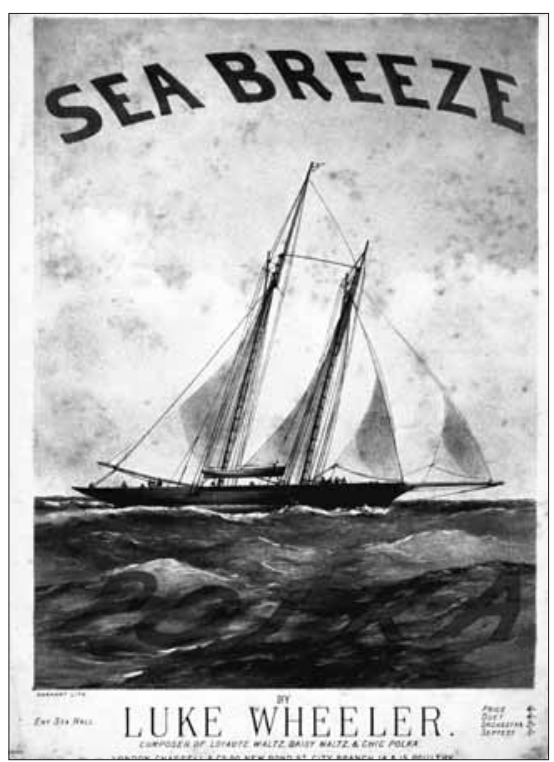

Figure 64. "Sea Breeze Polka" by Luke Wheeler. Chromolithographed sheet music cover, printed by M. \& N. Hanhart and published by Chappell \& Co., London. 335 x $255 \mathrm{~mm}$.

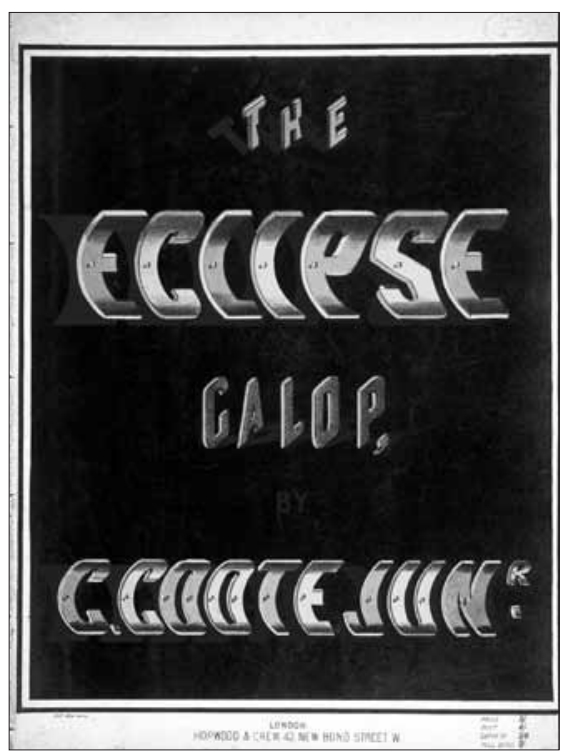

Figure 65. "The eclipse gallop" by C. Coote Jnr. Chromolithographed sheet music cover, published by Hopwood \& Crew, London. 347 x $255 \mathrm{~mm}$.

in time. But it would be difficult to argue that they played no part in preparing the world for the almost seamless relationship of picture and word in today's graphic communication.

I hope that I have provided enough evidence to conclude with the general observation that those who study either the history of printing or, more generally, social, business, and cultural history, without adequate consideration of ephemera, will form a highly restricted, or even distorted, view of their subject. Inevitably, such issues raise important and challenging questions for librarians and other curators regarding acquisitions, conservation, finding aids, and cataloguing.

It is true that artistic or literary merit, which curatorial staff of the Bodleian Library looked for in vain in the items it disposed of in the 1930s, is not the

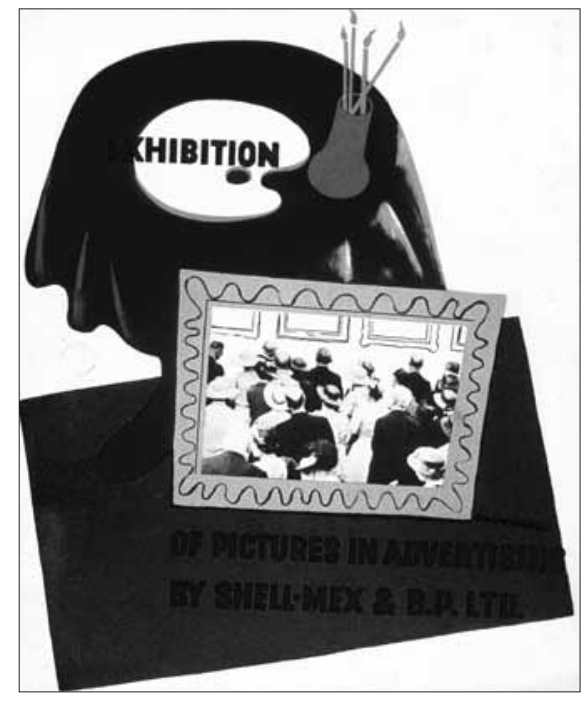

Figure 66. E. McKnight Kauffer, invitation to Shell-Mex \& BP Ltd exhibition, 1938. Lithographed in five colors with halftone inset. 203 $\mathrm{x} 172 \mathrm{~mm}$. 
most obvious feature of ephemera. But such judgments are notoriously fickle. And, even by commonly agreed canons of taste, we have to accept the artistic merit of a lithographed theater program, drawn and lettered by Edouard Vuillard in 1894, a poster executed by Toulouse Lautrec, or an invitation card designed in 1938 by the American designer, resident for most of his life in Britain, E. McKnight Kauffer (figure 66).

More significantly, if we want to catch the spirit of a period or flesh out the details of a particular occasion or situation, ephemera provide evidence of a kind not often found in other categories of documents. And if we seek to characterize the attitudes of a particular age and the nature of its language, it would be most unwise to exclude ephemera. What is more, our understanding of both graphic design and printing technology would be grossly incomplete if we took no account of the vast range of printed ephemera that has served society over the last few hundred years. I would argue, therefore, that studies of social and cultural history that discount printed ephemera are about as representative of their fields as studies of literature that take no account of the romantic novel or science fiction, or histories of architecture that ignore domestic and industrial buildings.

Illustration credits (otherwise from the author's collection): Amoret Tanner, 53-55; Bibliothèque nationale de France, 11; British Library (all rights reserved), 37 (Evanion 530), 63 (Evanion 2538); Centre for Ephemera Studies, The University of Reading, 1, 2, 3, 7, 35, 36, 46, 58, 60-61; Department of Typography \& Graphic Communication, The University of Reading, 12, 13, 56; Essex Record Office (reproduced by courtesy of), 25; John Johnson Collection, The Bodleian Library, Oxford, 4, 14, 24, 26, 29, 47, 49, 50; Reading University Library, 16, 17, 62; St. Bride Library, London, 15, 18, 20, 44; Sally de Beaumont, 52, 57; Valerie Jackson-Harris, 21.

\section{David M. Lesser Fine Antiquarian Books LLC \\ One Bradley Road \#302, Woodbridge, CT 06525 \\ Tel: (203) 389-8111 Fax: (203) 389-9113 \\ Email: dmlesser@lesserbooks.com Website: http://www.lesserbooks.com}

